\title{
IMPORTURI ȘI IMITAȚII DESCOPERITE ÎN DAVA DE LA POIANA AFLATE ÎN COLECȚIILE MUZEULUI NAȚIONAL DE ISTORIE A ROMÂNIEI
}

SORIN CLEŞIU

\author{
IMPORTS AND IMITATIONS DISCOVERED ON THE DAVA OF POIANA LOCATED \\ IN THE NATIONAL HISTORY MUSEUM OF ROMANIA COLLECTIONS
}

The items included in the catalogue were discovered following archaeological systematic excavations carried out between the years 1927-1928 and 1949-1950 in the Geto-Dacian site of Poiana and come from the collections of the National History Museum of Romania. From the lot of the available items, we succeeded in identifying a number of 44 relevant vessel fragments for our study, which are represented by Hellenistic and Roman items (34 Pontic sigillata) and Geto-Dacian vessels type imitations - drinking ware (cups, kantharoi, skyphoi) and service tableware (plates). The material is fragmentary, even so in a few cases the shape where restored rather precisely.

KEYWORDS: Pontic sigillata, Geto-Dacian settlement, imports, imitations, Roman pottery CUVINTE CHEIE: Pontic Sigillata, așezări geto-dace, importuri, imitaţii, ceramică romană

\author{
Within a context, items have \\ symbolic meanings \\ through their relationships \\ and contrasts with other \\ items within the same text
}

\section{CONSIDERAȚII PRELIMINARE}

În perioada preclasică în teritoriile locuite de geți ${ }^{2}$, importurile ${ }^{3}$ pătrundeau din lumea greacă şi apoi elenistică, prin intermediul cetăților pontice. Așadar, așezările de pe cursul inferior al Siretului ocupau poziţii de anvergură, iar vecinătatea cu oraşele greceşti le oferea un avantaj suplimentar transformându-le în centre artizanale şi comerciale de importanţă regională. Lotul de piese reprezentat de importuri şi imitații de la Poiana (com. Nicoreşti, jud. Galați) constituie subiectul prezentului studiu şi are ca scop includerea lor în circuitul știinţific.

Cetatea geto-dacică de la Poiana este localizată la marginea de nord-vest a satului Poiana, pe terasa râului Siret. Ocupă un platou cu o altitudine de $200 \mathrm{~m}$, puternic afectat în zilele noastre de eroziunile provocate de ape în râpele formate în substratul de loess și nisip; din întreaga staţiune păstrându-se numai periferia estică.

\footnotetext{
' Hodder, Hutson 2003, 144. A citi trecutul aşa cum o spune Ian Hodder - asemenea textului - în care cuvintele ca și vestigiile materiale, artefactele arheologice, necesită informaţii contextuale (deixis) pentru a transmite un sens, iată sensul motto-ului de mai sus. Astfel, asemeni cuvintelor cu ințeles deplin, vestigiile materiale iau formă temporală, spaţială, tipologică și funcțională.

${ }^{2}$ Dumitrescu, Vulpe 1988,92 . Cu precădere în spațiul est-carpatic, studiul de față referindu-se la importurile descoperite în așezarea de la Poiana Nicorești (jud. Galați). Atestaţi în izvoarele istorice în contextul campaniei lui Darius împotriva sciţilor, putem vorbi de geți (denumire etnică generică) încă din sec. VII a.Chr. Sursele îi amintesc la sud de Dunăre (Herodot, IV, 93, Tucidide, II, 96, 1), prima atestare a lor la nord de Dunăre aflându-se în contextul campaniei lui Alexandru cel Mare din 335 a.Chr. (Ptolemeu Lagos, la Arrian).

${ }^{3}$ Bauer 2008, 90-91. Atunci când identificăm un material/artefact, ne punem întrebarea dacă acesta reprezintă un produs local, de cine a fost realizat, unde a fost realizat. Toate aceste întrebări duc la catalogarea materialului respectiv ca import (venit din exterior) sau imitaţie (produs local) sau obiect realizat local reprezentând o „expresie a identităţii” (produs local, generând modele originale și stil propriu). Toate aceste variabile depind de procesele sociale de comerț, difuziune, migraţie, reglementate prin factori ai ,pieţei”, consumul, concurența şi relaţia economică, exportul și importul de idei.
} 
Primele cercetări arheologice au început în anul $1927^{4}$ sub conducerea lui Radu Vulpe, continuând cu mici întreruperi până în anul 1990. Stratigrafia staţiunii ${ }^{5}$ cuprinde o succesiune de mai multe niveluri de locuire aparținând epocii bronzului (cultura Monteoru), Hallstatt (cultura Basarabi) și Latène.

Sistemul defensiv al cetăţii de la Poiana ${ }^{6}$ este prezent numai pe laturile de est și de nordest, fiind constituit din val, palisadă şi şanţ de apărare, pantele abrupte (ce mărginesc aproximativ $2 / 3$ din suprafaţă) ale promontoriului oferind fortificarea naturală a aşezării.

Importurile şi imitațiile de la Poiana, reprezintă o constantă pentru determinarea și amploarea relațiilor comerciale și nu pot fi disociate. Imitarea amforelor și a veselei de băut, skyphos sau kantharos (formele cu decor lustruit sau pictat), a bolurilor elenistice cu decor în relief, iată temeiul pentru directa pondere a influențelor greco-elenistice și romane.

Majoritatea schemelor tipologice și morfologice ale formelor imitate corespund ceramicii elenistice și romane (secolele I a. Chr.-I p. Chr.). Imitațiile după vase de tip skyphos şi kantharos, spre exemplu, se individualizează printr-o profilatură încărcată, decor geometric lustruit (catalog nr. $35,37,38,39,42,43$ ), pereții groși ai corpului vaselor, pasta cenușie, compactă. Adoptarea prototipurilor originale se dezvoltă în produse locale realizate într-un stil propriu, influențele alogene generând, în cele din urmă, stilul figurativ unic de la Sarmizegetusa Regia.

Numărul mare al descoperirilor în spațiul est-carpatic, 1150 de exemplare publicate ${ }^{7}$ (imitații după vasele de tip kantharos si skyphos), ar putea indica împrumutul/influența tradițiilor grecești ${ }^{8}$ ce țin de symposion, ritualul dedicat băuturii (băutului în comun) şi deipnon al mesei propriu-zise ${ }^{9}$, de asemenea, al existenței unui serviciu de masă specializat (ministeria) format din vesela pentru băut (kantharoi, boluri) şi pentru masă (,fructiere”, străchini, castroane) ${ }^{10}$. Vasul specializat pentru transportul vinului - amphora - descoperită sub forma importurilor și imitațiilor, reprezintǎ o componentă esențială a schimburilor (vinuri scumpe) cu autohtonii ${ }^{1}$.

Sursele antice (Platon, Strabon - referitor la moravurile geților), clasifică neamurile barbare (sciții, perșii, celții, iberii, tracii și deopotrivă geții), ca fiind lipsite de măsură, vinul fiind consumat curat, fără apă - norma combinării vinului cu apa (krasis) în krateroi fiind o constantă a măsurii şi moderației. O ipoteză interesantă este emisă de Zoe Petre (susţinută inițial de Alexandru Avram), în studiul dedicat izvoarelor grecești referitoare la greci ${ }^{12}$, cu privire la interdicția de a bea vin în perioada lui Deceneu și Burebista. Astfel, este de presupus, ca ipoteză pur speculativă, că tradiția de interzicere a vinului, tăierea viței-de-vie, este legată de interdicția unor forme de cult legate de consumul ritual de vin (aşa-numita reformă a lui Deceneu) și de supunerea vremelnică a aristocrației războinice în timpul lui Burebista.

Problematica ceramicii elenistice și romane a fost readusă în discuție de Mariana-Cristina Popescu, prin articole despre categoriile ceramice studiate (Sigillata Pontica ${ }^{13}$, ceramica pergameniana ${ }^{14}$, ceramica glazurată ${ }^{15}$ ) concretizate ulterior într-un studiu intitulat Hellenistic and Roman Pottery in pre-Roman Dacia: (2 $2^{\text {nd }}$ century B.C. - $I^{s t}$ century A.D.), monografie dedicată descoperirilor de acest gen în așezările și fortificațiile getice.

\footnotetext{
${ }^{4}$ Vulpe, Vulpe 1931, 93-130

${ }^{5}$ Vulpe, Teodor 2003, 15-22

${ }^{6}$ Vulpe, Teodor 2003, 89-95

7 Florea 1998, 106-108; Florea 2011, 83

8 Vasele de tip kantharos fiind probabil produse şi exportate în regiunile învecinate.

9 Petre 2004, 175-179 (cu notele și trimiterile bibliografice) tema băutului în comun (symposion) fiind tratată riguros în literatura. de specialitate.

${ }^{10}$ Florea 1998, 106

11 Opait 2013, 21-65

12 Petre 2004, 178

${ }^{13}$ Popescu 2009, 17-46

${ }^{14}$ Popescu 2010, 51-66

${ }^{15}$ Popescu 2012, 8-10
} 


\section{CERAMICA DE IMPORT ȘI IMITATTIILE GETICE DE LA POIANA AFLATE ÎN DEPOZITUL MUZEULUI NAȚIONAL DE ISTORIE A ROMÂNIEI}

\section{II.1. CONTEXTUL RECENT \$I ARHEOLOGIC}

În studiul de față nu mi-am propus să intru în problematica ceramicii elenistice și romane, ci doar să completez lotul de piese reanalizat recent ${ }^{16}$, cu cele care au stat mai bine de două decenii în depozitele muzeului. Un demers similar l-am întreprins odată cu studierea ceramicii cu pictură de la Sarmizegetusa Regia, piesele care fac obiectul studiului de faţă având aceeași istorie ${ }^{17}$.

Ceramica descrisă în catalog a fost selectată dintr-un lot de aproximativ 100 de piese păstrate în colecțiile Muzeului Național de Istorie a României. Am ales să repertoriez piesele de import și câteva din piesele getice considerate imitații locale.

Restul de piese (netratate în studiul de faţă), este alcătuit din fragmente ceramice tipice pentru perioada clasică Latène. Printre acestea s-a „rătăcit” și un vas reîntregibil de dimensiuni mari (probabil un vas de provizii?), cu decor în val, descoperit de Vasile Pârvan în timpul perieghezei efectuate în anul 1913, la Poiana.

În contextul numărului impresionant de obiecte ceramice autohtone și de import, cele câteva piese selectate și descoperite în mod insolit în depozitul MNIR nu schimbă din punct de vedere statistic situația materialului de la Poiana, ci reprezintă o categorie, un eșantion pentru studiul comparativ. Adăugăm şi faptul că deși o parte din piesele de import de la Poiana au fost reanalizate, studiile privind delimitarea producțiilor locale de cele de import sunt puține ca număr, reprezentând una dintre problemele cu care se confruntă cercetarea actuală în această chestiune.

Depozitate într-o cutie de carton, pe care era notația „Poiana” fragmentele ceramice neîntregibile au fost disociate pe baza marcajului notat în cerneală cu penița.

Pe baza marcajului de pe unele dintre piesele selectate, am putut reconstitui într-o oarecare măsură contextul arheologic. Pe o parte din fragmente există doar sigla șantierului şi anul (Poiana 1949), pe altele, deși lipsește anul, este notată secțiunea (o parte fiind descoperite cu prilejul demontării unui profil), sau suprafața în care au fost descoperite și, în sfârșit, fragmente notate doar cu menținea „Poiana”.

Aşadar, contextul arheologic este neclar, fragmentele ceramice fiind obiectul cercetărilor realizate în anii 1927 - 1928 și 1949 - 1950. Mai precis, este vorba de secțiunea B', orientată E-V şi trasată în prelungirea secțiunii $B$, cercetată în anul 1927, a celor notate $H-H$ '-H' (în zona vestică a stațiunii) și C'-C" (perpendiculare pe valul de apărare de pe latura de est a stațiunii cercetate în $1949-1950)^{18}$ și în cele din urmă, a pieselor rezultate la demontarea unui profil al secțiunii $\mathrm{K}^{19}$, spre capătul sudic al aşezării. În secțiunea $\mathrm{K}$ din anul 1950 a fost descoperită o locuință de formă dreptunghiulară identificată datorită gropilor de par, podelei și vetrelor.

\section{II.2. TIPOLOGIA FORMELOR}

Formele studiate respectă în cadrul repertoriului tipologiile predefinite și împărțirea în două grupe funcționale: veselă de masă și vase pentru transport sau depozitare.

Astfel, din lotul avut la dispoziție pentru studiu, alcătuit din cupe, skyphoi, farfurii și amfore, au fost identificate 33 forme aparținând veselei de import și 16 forme aparținând imitațiilor getice.

\section{II.2.1. IMPORTURILE}

$\mathrm{Au}$ fost identificate mai multe clase ceramice prezente în lotul avut la dispoziție pentru studiu:

\footnotetext{
${ }^{16}$ Popescu, 2009, 17-46, Popescu 2013.

${ }^{17}$ Cleşiu, Trohani 2013, 207

18 Vulpe 1951, 47-52. Cercetările arheologice din anul 1949 au fost publicate într-un scurt raport în primul număr al revistei Studii și Cercetări de Istorie Veche, responsabilul ştiințific fïnd R. Vulpe, din colectivul de cercetare făcând parte și I. Casan, C. Cihodaru, S. Constantinescu, Gr. Florescu, M. Grigorașu, P. Radu, de asemenea, semnatari ai "Raportului sumar despre activitatea şantierului arheologic Poiana-Tecuci”.

${ }^{19}$ "Vulpe, Teodor 2003, 31
} 
A. Ceramica cu decor pictat West Slope. Stilul ceramic West Slope, apare în atelierele din centrele de la Atena și Pergam, precum și în centrul cunoscut sub numele de Ivy Platter Workshop din regiunea micro-asiatică ${ }^{20}$, cu localizare incertă. Stilul se dezvoltă începând cu primul sfert al secolului al III-lea și se caracterizează prin motive decorative vegetale, geometrice, zoomorfe, pictate cu alb/galben-brun pe barbotina de culoare închisă sau prin motive realizate prin incizie, ornamente aplicate sau lustruire. În siturile getice de la Brăilița, Bordușani, Popești, Poiana, Răcătău și Brad, vasele cu decor West Slope sunt destul de bine reprezentate de skyphoi, cupe și kantharoi, cu decor simplu, alcătuit din motive vegetale sau geometrice, foarte puține sunt decorate prin incizie, motive aplicate sau incizie ${ }^{21}$

Această categorie ceramică este reprezentată în repertoriul nostru de un singur fragment aparținând unui vas skyphos. Acesta păstrează toarta pliată la partea superioară, rotunjită. Pe fragmentul păstrat din corp se află urmele de vopsea albă la joncțiunea dintre perete și bază. Pasta este fină, compactă de culoare cărămizie, firnis roșcat, decorat cu motive pictate (cat. nr.7).

Cronologic, se încadrează între mijlocul secolului al II-lea a. Chr. și mijlocul secolului I a. Chr. şi probabil reprezintă o adaptare în centrele pontice a vaselor de tip skyphoi, produse în Pergam sau Asia Minor ${ }^{22}$

\section{B. Sigillata pergameniană}

Categorie ceramică a vaselor cu firnis de culoare roșie „rotfirniskeramik”, denumită şi sigillata orientală, a fost creată de-a lungul secolului al II-lea a. Chr. în centre din Asia Mică, mai precis în Pergam, sudul Asiei Mici sau în centre neidentificate din Siria şi Palestina. Fragmente aparținând acestei categorii au fost descoperite la Bordușani, Popești, Poiana, Răcătău şi Brad.

$\mathrm{Au}$ fost identificate două forme ceramice: vas cu picior, posibil o cupă? sprijinită pe un picior plat, suplu, cu marginea profilată având o canelură pe margine (cat. nr. 21) şi un fragment din partea superioară a unui castron cu buza fațetată, peretele vasului înclinat și concav la interior. Acesta din urmă încadrându-se formei Atlante II, tip L26A, ceramică produsă în Çandarli, conform clasificării lui J.W. Heyes ${ }^{23}$ (cat. nr. 30).

\section{Sigillata pontica}

Sigillata Pontica, nume convențional pentru descoperirile din bazinul pontic, reprezintă cea mai numeroasă categorie ceramică, majoritatea provenind din așezările getice de pe Valea Siretuluii $^{24}$. Pentru clasificarea ${ }^{25}$ acestora se evidențiază două studii tipologice majore. Primul aparține lui J. W. Hayes în Atlante II, pe baza materialelor descoperite în bazinul pontic ${ }^{26}$. Al doilea, cel mai recent, este realizat de Denis V. Zhuravlev pe baza materialelor arheologice obținute din necropola scitică din sud-vestul Crimeei (Belbek III și IV) ${ }^{27}$.

Ținând seama de starea de conservare a vaselor studiate, tipologia realizată de MarianaCristina Popescu grupează piesele în două categorii funcționale: vase pentru servit (farfurii și boluri) și vase pentru băut (pahare, cupe și skyphoi $)^{28}$. Caracteristicile principale ale acestui grup ceramic, sunt date de pasta omogenă cu mică și particule calcaroase în compoziție, culoarea variabilă (roşu, cărămiziu sau brun), firnis dispus inegal având reflexie strălucitoare sau mată. Pentru realizarea decorului erau utilizate mai multe tehnici de ornamentare - incizie, motive aplicate, imprimare și barbotinare.

În cadrul materialului ceramic studiat, au fost identificate fragmente aparținând cupelor, vaselor de tip skyphoi și farfuriilor.

\footnotetext{
${ }^{20}$ Popescu 2011, 52.

${ }^{21}$ Popescu 2013, 34. Înregistrarea și analizarea a 89 de fragmente prezente în siturile dacice din afara arcului carpatic.

${ }^{22}$ Popescu 2013, 37.

${ }^{23}$ Atlante II, 77. Tipologia lui Heyes se bazează pe formele prezentate de Loeschcke, dar si pe baza tipurilor descoperite în Pergam sau în alte situri din jurul Mării Mediterane.

${ }^{24}$ Pentru Poiana sunt 184 de intrări în catalogul ceramic realizat de Mariana-Cristina Popescu. Pentru comparație, la Răcătău au fost descoperite 90 de fragmente, iar la Brad numai 27.

${ }^{25} \mathrm{Nu}$ intru în detalii și considerații de ordin tipologic, menționez doar cele două direcții de studiu.

${ }^{26}$ Atlante II, 92-96.

${ }^{27}$ Zhuravlev 2002, 256-261.

${ }^{28}$ Popescu 2013, 68-73
} 
Cupele sunt reprezentate de 6 fragmente determinate: cupe cu corpul globular, buza teșită sau rotunjită, toarte inelare. Conform tipologiei propuse de Mariana-Cristina Popescu se încadrează în tipul C 2/ varianta 1, după Zhuravlev tipul $32.5^{29}$.

Un fragment cu toarta inelară prinsă de corp păstrează decorul barbotinat realizat din picături în formă de lacrimă dispuse în șir în partea superioară a corpului (cat. nr. 1), restul fragmentelor sunt reprezentate de un fragment din corp şi mai multe baze de formă inelară.

Vasele de tip skyphos sunt reprezentate printr-un număr de 5 fragmente determinate, reprezentând cele mai multe intrări din catalogul nostru.

Sunt două variante de vase cu corpul tronconic, unghiular (cat. nr. 10, 16) sau rotunjit (cat. nr. 8) la joncțiunea dintre perete și bază, cu toarte inelare cu plăcuță, tip S 2 Popescu (Atlante II, tip $\mathrm{X} \mathrm{A}, \mathrm{B})$.

Restul vaselor, fie ele fragmente de buze, corp sau bază, se încadrează în categoria miscellanea, varianta cu corpul tronconic, unghiular la joncțiunea dintre perete și bază sau varianta cu corpul tronconic rotunjit la joncțiunea dintre perete şi bază, dar cu toarte pliate la partea superioară.

Farfuriile, cuprinzând fragmente din 6 exemplare, se încadrează în două variante. Farfurie cu buză verticală şi muluri pe suprafaţa exterioară, tip P 1/varianta 2 Popescu (Atlante II, tip I, Zhuravlev 2010, nr. 61). A doua variantă este reprezentată de farfuria cu corpul având pereții arcuiți și buza rotunjită, teșită sau înclinată spre interior, tip P 3/varianta 1 Popescu (Zhuravlev 2010, tipurile $11.1,11.2$ și 12).

D. Amforele sunt reprezentate de două toarte fragmentare de amforă aparţinând probabil unor amfore pseudo Cos (imitații Heracleea Pontica). Toartele sunt bifide, arcuite formând un unghi ascuțit; pasta este de culoare alb-roziu, fină, compactă, foarte dură, cu particule albe, calcaroase, mică, cuarț.

Aceste tip de amfore reprezintă imitații ale amforei cosiene, produse în centrele de la Heracleea și Sinope și vor domina spațiul pontic în perioada romană, frecvența acestor piese fiind mare în toate așezările de pe Valea Siretului.

\section{II.2.2. IMITAȚIILE GETICE.}

Imitațiile getice sunt reprezentate de vase de tip kantharos, skyphos, lagynos.

\section{A. Ceramică cenușie.}

Fragmente ceramice cu decorul lustruit pe suprafața mată a angobei cenușii, realizat din benzi lustruite dispuse vertical, orizontal sau oblic, unele formând triunghiuri. Corpul acestora este bitronconic în majoritatea cazurilor, două exemplare având corp cilindric, cu partea inferioară de formă tronconică. Toartele sunt inelare, unele prezintă caneluri sau sunt aplatizate la partea superioară, baza este inelară în majoritatea cazurilor.

Tehnica în care sunt realizate aceste vase, angobarea și lustruirea acesteia, ar putea ilustra o fază timpurie, de tranziție spre tehnica picturii propriu-zise de origine elenistică.

\section{B. Ceramică cu decor pictat.}

Trei fragmente din catalog sunt reprezentate de două vase skyphoi cu decor geometric pictat, cu benzi roşii orizontale care încadrează linii oblice sau neregulate, (nr. catalog 13, 14) și de un fragment din corpul unui vas lagynos, decorat cu benzi și triunghiuri de culoare roșie.

La cele trei fragmente studiate, adăugăm si un fragment de skyphos cu corp tronconic, unghiular la joncțiunea dintre perete şi bază, cu buza rulată și rotunjită la exterior; toarta verticală, pliată, cu o ușoară șănțuire la partea superioară.

Culoarea pastei variază de la un alb-gălbui spre cărămiziu și are în compoziție, nisip, oxizi de fier, incluziuni de culoare neagră (cărbune, pleavă ?), sau particule calcaroase. Firnisul vaselor este de culoare alb-gălbui, peste care au fost aplicate motivele decorative pictate sau de culoare roșiatică, dispus inegal și fără alte elemente decorative. 
Tehnica olăriei meșterilor locali, desăvârşită uneori, ne permite cu greu disocierea vaselor imitate de vasul utilizat ca model, toate fragmente sunt produse autohtone decorate în stil elenistic $^{30}$, cu o bună execuție tehnică.

\section{III.2. EXCURS. CONCLUZII ȘI DATE DESPRE PERIOADA FINALĂ A AȘEZĂRII DE LA POIANA}

Sigillatele pontice sunt realizate în centre din bazinul pontic rămase necunoscute din punct de vedere arheologic. Cronologic ${ }^{31}$, formele au fost produse de-a lungul primei jumătăți a secolului I p. Chr.

Mariana-Cristina Popescu stabilește prima jumătate a secolului I p.Chr. ca terminus post quem pentru apariția sigillatelor pontice în așezările getice (skyphoi varianta Atlante II X A, B). De asemenea, formele datate după Hayes și Zhuravlev în secolul al II-lea p. Chr., perioadă în care dezvoltarea acestor davae se va fi încheiat datorită cuceririi romane, devin terminus ante quem pentru răspândirea acestora în Dacia pre-romană.

Astfel, tipul P1/varianta 2 se încadrează după Zhuravlev în intervalul cronologic absolut 50-240/250 p. Chr., iar tipul P3/varianta 1 în intervalul 50-100 p.Chr.

Din punct de vedere cronologic, dava de la Poiana are o evoluție continuă ${ }^{32}$ acoperind perioada cuprinsă între sfârșitul secolului al IV-lea a. Chr. şi finalul secolului I p. Chr./începutul secolului al II-lea p. Chr. Acest lucru este susținut de indicatori cronologici relevanți cum ar fi fibulele de schemă tracică, fibulele Latène B şi C, amforele Thasos cu ştampilă, fibulele Aucissa, fibulele norico-panonice sau fibulele în formă de pelta sau lunula.

Este importantă mențiunea dată de însemnările papyrusului Hunt care conține referiri despre dislocarea efectivelor cohortei I Hispanorum veterana quingenaria, din trupele aflate în Moesia Inferior. Astfel, se menționează că o parte din aceste efective se aflau trans Danuvium in expeditionem, alții erau intra provinciam, Piroboridavae ${ }^{33}$ in praesidio, Buridavae in vexillatione ${ }^{34}$.

$\mathrm{Nu}$ se pot determina cu certitudine aspectele privind funcționarea acestor centre în perioada celor două războaie dacice. De asemenea, identificarea celor două centre conform textului geografului Ptolemeu ${ }^{35}$ - Piroboridava cu Poiana de pe Siret şi Buridava la Stolniceni - Râmnicu Vâlcea, rămâne ipotetică. Sistemul de fortificații de la Poiana funcționează o perioadă scurtă de timp, la finalul secolului I p. Chr. acesta fiind abandonat, nivelul de distrugere identificat în zona valului de apărare fiind legat de expediția lui Tiberius Plautius Silvanus Aelianus, în urma căreia 100.000 de transdanubieni sunt strămutați în provincia Moesia. Este foarte probabil ca această așezare să fỉ renunțat la funcția militară de ceva vreme (finalul anului $89 \mathrm{p}$. Chr.), dată fiind situația fortificației abandonate și numărul redus de piese de armament corespunzător tipologic acestei perioade (un singur fragment aparținând unui vârf de lance de tip pilum și două fragmente incerte, restul fiind fragmente de lance încadrate timpuriu și vârfuri de săgeți din bronz cu trei muchii ${ }^{36}$ ). Este cert faptul, că după repetatele strămutări, dar și a numeroaselor înfrângeri prin acțiunile hotărâtoare ale guvernatorilor romani, dar şi datorită presiunii exercitate odată cu organizarea provinciei Moesia, geții își pierd coeziunea politică și militară. Astfel, cu destulă probabilitate, este de presupus că statutul davei de la Poiana, la finalul secolului I p. Chr. poate începutul secolului al II-lea p. Chr. este cu precădere comercial (port of trade), teritoriile de la sud de Carpați și sudul Moldovei aparținând la data redactării pridianum-ului (105 p. Chr.), provinciei Moesia Inferior ${ }^{37}$.

\footnotetext{
${ }^{30}$ Florea $1998,99-108$

${ }^{31}$ Popescu 2013, 76, tabel 2

${ }^{32}$ Din nefericire informațiile privind contextul arheologic sunt lacunare sau lipsesc cu desāvârşire. Datoritã acestui lucru nu putem face observații detaliate privind sfârșitul cronologic al aşezării de la Poiana și orice demers în acest sens se încadrează în limitele prudenței.

${ }^{33}$ Vulpe, Teodor 2003

${ }^{34}$ Fontes I, 467-471; Syme 1971, 122; Petolescu 2010, 162-163

${ }_{35}$ Ptolemeu, Geographia, III, 8, 5.

${ }^{36}$ Vulpe, Teodor 2003, 532-540, fig. 53-61

${ }^{37}$ Petolescu 2010, 162-163 (și nota 15 despre datarea papirusului, conform inscripţiei de la Rasova, jud. Constanţa)
} 
CATALOG $^{38}$

\section{IMPORTURILE}

\section{CUPE}

1. Cupă cu corpul globular şi toartă inelară (Zhuravlev, tip 32.5). Cercetări arheologice 1949; $D g=8 \mathrm{~cm}, D \boldsymbol{m}=8,50 \mathrm{~cm}$. Fragmentar. Buza verticală, rotunjită la exterior; corpul este globular cu două toarte prinse de acesta. Dec. barbotinat; omamentat cu picături în formă de lacrimă dispusă în partea superioară a corpului; pasta este fină, compactă de culoare cărămizie, 7,5YR7/6; firmis dispus inegal de culoare roșcată cu aspect metalic, 7,5YR8/8.

Cf. Zhuravlev 2002, 256, fig. 12/9. Ref. Vulpe, Teodor 2003, nr. 849, p. 328, fig. 239/7; Popescu 2009, nr. 93, p. 32-33, pl. 4; Popescu 2013, nr. 261, 262 , p. 137,228 . Dat. mijlocul sec. I p. Chr. sfârşitul sec. I p. Chr./prima decadă a sec. II p. Chr. Pl. I/1, IX/1

2. Cupă cu corpul globular, buză rotunjită sau teşită, toartă inelară (Zhuravlev, tip 32.5). Cercetări arheologice 1949; $\boldsymbol{D g}=8 \mathrm{~cm}$. Fragmentar. Corp globular, buză verticală teșită; două caneluri la joncțiunea buzei cu peretele corpului; pasta este de culoare cărămizie, fină, compactă cu mică şi incluziuni calcaroase în degresant, 10YR7/6; fimis de culoare roşcată cu reflexii metalice, 7.5YR7/8. Cf. Zhuravlev 2010, nr. 235-236, 238, p. 148-149, pl. 30. Ref. Popescu 2009, nr. 174, p. 40; Popescu 2013, tip C4, p.228, Pl. 18, 48/315. Pl. I/2, IX/2

3. Cupă cu corpul globular, buză rotunjită sau teşită, toartă inelară (Zhuravlev, tip 32.5). Cercetări arheologice $1949, \boldsymbol{D b}=5 \mathrm{~cm}$. Fragmentar. baza de formă inelară, uşor supraînălțată; pasta este de culoare cărămizie, 5 YR6/8, poroasă, cu incluziuni calcaroase şi particule brune (oxizi de fier?). Vasul a fost acoperit cu o angobă de culoare brun-roșcată cu reflexii metalice, dispusă inegal, 5YR6/6. Cf. Zhuravlev 2010, nr. 235-236, 238, p. 148-149, pl. 30. Ref. Popescu 2009, nr. 174, p. 40; Popescu 2013, tip C4, p.137, Pl. 50/411. Dat. mijlocul sec. I p. Chr. - sfârşitul sec. I p. Chr./prima decadă a sec. II p. Chr. Pl. I/3, IX/3

4. Cupă cu corpul globular, buză rotunjită sau teșită, toartă inelară (Zhuravlev, tip 32.5). Cercetări

\footnotetext{
38 Organizarea catalogului: Numărul curent; Categorie obiect (formă vas, grup funcțional); context arheologic; Dimensiunile și starea de conservare a obiectului; Descriere morfologică; Decor; Analogii; Referințe bibliografice; Datare; Note și observaţii, Planşă. Abrevieri folosite în catalog: Sect. - secțiune, Dec. decor, Cf. - conform, Dat - datare, Notă - observaţii, Ref. - referințe bibliografice analogii; $\boldsymbol{L}=$ lungime, $\boldsymbol{l}=$ lățime; $\boldsymbol{H}_{\boldsymbol{\rho}}=$ înălțimea pástrată; $\boldsymbol{D}_{g}=$ diametrul gurii; $\boldsymbol{D}_{\boldsymbol{m}}=$ diametrul maxim; $\boldsymbol{D} \boldsymbol{b}=$ diametru bază; PI. planșă.
}

arheologice $1949 ; \boldsymbol{D b}=4 \mathrm{~cm}$. Fragmentar. Baza de formă inelară, înălțată, cu umbo în centru; pasta este de culoare gălbuie-roșiatică, fină, compactă, cu mică şi oxizi de fier 2,5YR6/8. Cf. Zhuravlev 2010, nr. 235-236, 238, p. 148-149, pl. 30. Ref. Popescu 2009, nr. 174, p. 40; Popescu 2013, tip C4, p.137, Pl. 50/410,417. Dat. mijlocul sec. I p. Chr. sfârşitul sec. I p. Chr./prima decadă a sec. II p. Chr.

\section{Pl. I/4, IX/4}

5. Cupă cu corpul globular, buză rotunjită sau teșită, toartă inelară (Zhuravlev, tip 32.5). Cercetări arheologice 1949; Sect. B' C 12, 1949 ?; Db $=4$ $\mathrm{cm}$. Fragmentar. Baza de formă inelară, înălțată, cu umbo în centru; Pasta este de culoare cărămizie, 2,5YR6/8, compactă, cu mică și incluziuni albe (calcaroase). Cf. Zhuravlev 2010, nr. 235-236, 238, p. 148-149, pl. 30. Ref. Popescu 2009, nr. 174, p. 40; Popescu 2013, tip C4, p.137, Pl. 50/410,417. Dat. mijlocul sec. I p. Chr. - sfârșitul sec. I p. Chr./prima decadă a sec. Il p. Chr. Pl. I/5, IX/5

6. Cupă cu corpul globular, buză rotunjită sau teşită, toartă inelară (Zhuravlev, tip 32.5). Cercetări arheologice $1949, \boldsymbol{D b}=5 \mathrm{~cm}$. Fragmentar. Baza de formă inelară, uşor supraînălțată; pasta este de culoare cărămizie, 5 YR6/8, poroasă, cu incluziuni calcaroase şi particule brune (oxizi de fier?). Cf. Zhuravlev 2010, nr. 235-236, 238, p. 148-149, pl. 30. Ref. Popescu 2009, nr. 174, p. 40; Popescu 2013, tip C4, p.137, Pl. 50/411. Dat. mijlocul sec. I p. Chr. - sfârşitul sec. I p. Chr./prima decadă a sec. II p. Chr. Pl. I/6, IX/6

\section{SKYPHOI}

7. Skyphos (West Slope) având corpul cu pereți verticali înclinați spre interior, unghiular la joncțiunea peretelui cu baza, toartă pliată la partea superioară. Cercetări arheologice 1949 ?, PI. II/7, X/10 Toartă verticală, pliată la partea superioară; pastă de culoare cărămizie, $10 \mathrm{YR} 8 / 4$, fină, cu particule de mică şi uşoare incluziuni calcaroase; firnis de culoare roșcată 5YR6/8. Dec. pictat; se păstrează foarte puţin din decorul format probabil din benzi şi motive vegetale realizate cu vopsea albgălbuie. Popescu 2013, p. 37, Pl. 1-2/47-71. Dat. mijlocul sec. II a. Chr. şi mijlocul sec. I a. Chr. Pl. II/7, PI. X/10

8. Skyphos având corpul cu pereți verticali înclinați spre interior, unghiular la joncțiunea peretelui cu baza, toartã pliată la partea superioară ${ }^{39}$. Cercetări arheologice 1949 ?, Sect. B' C 12, Dm = $8 \mathrm{~cm}$. Fragmentar. Toartă verticală, pliată la partea superioară; pastă de culoare cărămizie, $5 Y R 7 / 6$, fină, cu particule de mică și oxizi de fier, ușoare incluziuni albe (calcaroase); firnis de culoare brunroşiatică cu reflexii metalice, dispus inegal pe interiorul și exteriorul vasului, 5YR7/8. Ref.

\footnotetext{
${ }^{39}$ Popescu 2013, 103, nr. 49
} 
Popescu 2013, p. 103, nr. 49; p. 107, nr. 79. Dat. sfârșitul sec. II a. Chr. - sec. I p. Chr. Pl. II/8, X/11 9. Skyphos cu corpul tronconic, unghiular sau rotunjit la joncțiunea dintre perete şi bază, cu toarte inelare cu plăcuță (Atlante II, tip XA, B). Cercetări arheologice 1949; $\mathbf{D m}=8 \mathrm{~cm}$. Fragmentar. Corpul tronconic al vasului, rotunjit la joncțiunea dintre perete şi bază. Pasta este fină, de culoare albgălbuie, cu particule de mică aurie şi oxizi de fier, 7,5YR6/4. Vasul a fost acoperit cu o angobã de culoare brun-cărămizie la exterior şi interior, cu reflexie metalică, dispusă inegal, 7.5YR4/6, urme de ardere secundară. $C f$. Atlante II, p. 94-95, pl. XXIII/10, 11. Ref. Vulpe, Teodor 2003, no. 850, p. 328, fig. 239/8; Zhuravlev 2002, 256, fig. 12/12, 14, 259, fig. 15/5; Popescu 2009, nr. 41, p. 28, fig. 3; Popescu 2013, p. 162, Pl. 53. Dat. de la începutul şi până la finalul sec. I p. Chr. PI. II/9, X/7

10. Skyphos cu corpul tronconic, unghiular la joncțiunea dintre perete şi bază, cu toarte pliate la partea superioară. Cercetări arheologice 1949, Dm $=7 \mathrm{~cm}$. Fragmentar. Corp tronconic, unghiular la joncțiunea peretelui cu baza, toarta pliată la partea superioară este ruptă la jumătate; pasta este dură, compactă, cu mică și incluziuni calcaraose, 7,5YR7/8; firnis de culoare roşiatică 7.5YR6/8. Ref. Popescu 2013, p. 180-181. Dat. sec. I p. Chr. Pl. II/10, X/8

11. Skyphos cu corpul tronconic, unghiular sau rotunjit la joncțiunea dintre perete și bază, cu toarte inelare cu plăcuță ${ }^{40}$. Cercetări arheologice 1949 , $D \boldsymbol{m}=10 \mathrm{~cm}$. Fragmentar. Corpul tronconic al vasului, unghiular la joncțiunea dintre perete și bază. Dec. barbotinat?; Pasta de culoare alb-gălbuie este compactă, cu mică aurie și incluziuni albe, calcaroase, 5YR7/6; angobă de culoare roşiatică, dispusă inegal, 5YR6/8. Cf. Atlante II, p. 94-95, pl. XXIII/10, 11. Ref. Vulpe, Teodor 2003, no. 850, p. 328, fig. 239/8, Zhuravlev 2002, 256, fig. 12/12, 14, 259, fig. 15/5, Popescu 2009, no. 41, p. 28, fig. 3 , Popescu 2013, p. 162, Pl: 53. Dat. de la începutul şi până la finalul sec. I p. Chr. ${ }^{41}$ Pl. II/11, X/9

12. Skyphos? Cercetări arheologice 1928, secțiunea B' C 12, Dg. 9 cm. Fragmentar. Buza este înclinată la exterior, uşor aplatizată; pastă fină de culoare cărămizie, cu incluziuni calcaroase, oxizi de fier, 5 YR7/6. Ref. Popescu 2013, p.180, nr. 577, 594. PI. II/11; X/12

\section{VARIA}

13. Skyphos cu corpul tronconic, unghiular sau rotunjit la joncțiunea dintre perete şi bază, cu toarte inelare cu plăcuță (Atlante II, tip XA, B). Cercetări arheologice $1949 ; D m=8,80 \mathrm{~cm}, D b=4 \mathrm{~cm}$. Fragmentar. Corpul tronconic al vasului, unghiular la joncțiunea dintre perete și bază. Baza este inelară, ușor profilată și supraînălțată. Pasta este

\footnotetext{
${ }^{40}$ Popescu 2013, tip S2, 161

${ }^{41}$ Popescu 2013, 161
}

fină, compactă de culoare cărămizie, cu mică și incluziuni calcaroase, 2,5YR5/8; angobă de culoare brun-roşiatică dispusă inegal, 2.5YR4/8. Cf. Atlante II, p. 94-95, pl. XXIII/10, 11. Ref. Vulpe, Teodor 2003 , no. 850 , p. 328 , fig. $239 / 8$, Zhuravlev 2002 , 256, fig. 12/12, 14, 259, fig. 15/5, Popescu 2009 , nr. 41 , p. 28, fig. 3, Popescu 2013, p. 162, Pl. 53. Dat. de la începutul şi până la finalul sec. I p. Chr. Pl. III/13

14. Skyphos cu corpul tronconic, unghiular sau rotunjit la joncțiunea dintre perete și bază, cu toarte inelare cu plăcuță (Atlante II, tip X/A, B). Cercetări arheologice 1949; $\boldsymbol{D} \boldsymbol{b}=4,30 \mathrm{~cm}$. Fragmentar. Corpul tronconic al vasului, unghiular la joncțiunea dintre perete şi bază; baza de formă inelară, profilată, supraînălțată; pasta este de culoare cărămizie, compactă, cu mică și incluziuni calcaroase in degresant, 5YR6/6; firmisul nu se păstrează. $C f$. Atlante II, p. 94-95, pl. XXIII/10, 11 . Ref. Vulpe, Teodor 2003, no. 850 , p. 328, fig. 239/8, Zhuravlev 2002, 256, fig. 12/12, 14, 259, fig. 15/5, Popescu 2009, nr. 41, p. 28, fig. 3, Popescu 2013 , p. 162 , Pl. 53. Dat. de la începutul şi până la finalul sec. I p. Chr. PI. III/14

15. Skyphos cu corpul tronconic, unghiular sau rotunjit la joncțiunea dintre perete și bază. Cercetări arheologice 1949 ?, B' C 12, Dm =8,30 cm, Db $=$ $4,50 \mathrm{~cm}$. Fragmentar. Corpul tronconic al vasului, unghiular la joncțiunea dintre perete și bază; baza de formă inelară, profilată, supraînălțată; pasta este de culoare cărămizie, incluziuni calcaroase, oxizi de fier, cărbune, nisip, 7,5YR6/6. Dat. sec. I p. Chr. Pl. III/15

16. Skyphos cu corpul tronconic, unghiular la joncţiunea dintre perete şi bază, cu toarte pliate la partea superioară. Cercetări arheologice 1949 ?, Sect. K, demantelare profil ? carourile 2-5, Db $=4$ $\mathrm{cm}$. Fragmentar. Baza de formă inelară, profilată şi uşor supraînălțată; pasta de culoare cărămizie, conţine particule de mică şi incluziuni calcaroase, 2,5YR5/8. Fimis de culoare roșie dispus inegal, 7,5YR7/6. Ref. Popescu 2013, p.180, nr. 577. PI. III/16

17. Skyphos cu corpul tronconic, unghiular la joncțiunea dintre perete şi bază, cu toarte pliate la partea superioară. Cercetări arheologice 1949 ?, Sect. K, demantelare profil ? carourile 6-8, Db $=$ $4,50 \mathrm{~cm}$. Fragmentar. Baza inelară, profilată şi uşor supraînălțată; pasta este de culoare alb-gălbuie, cu mică, oxizi de fier și incluziuni calcaroase în degresant, 7,5YR7/6. Ref. Popescu 2013, p. 180, nr. 577. PI. III/17

18. Skyphos cu corpul tronconic, unghiular la joncțiunea dintre perete şi bază, cu toarte pliate la partea superioară. Cercetări arheologice 1928, Secț. B' C 12, Db $=5,30 \mathrm{~cm}$. Fragmentar. Corpul de formă tronconică cu baza vasului de formă inelară, profilată; pasta de culoare cărămizie, cu mică și incluziuni calcaroase, 7,5 YR, 6/6; firnis de culoare 
roşie dispus inegal. Ref. Popescu 2013, p. 180, nr. 577, 591. Dat. sec. I p. Chr. PI. III/18

19. Skyphos cu corpul tronconic, unghiular la joncțiunea dintre perete şi bază. Cercetări arheologice 1949, $\boldsymbol{D b}=5 \mathrm{~cm}$. Fragmentar. Corp tronconic unghiular la joncțiunea dintre perete şi bază; baza inelară, ușor supraînălțată cu o canelură pe marginea exterioară; pasta este de culoare cărămizie, fină, compactă, cu particule de mică și incluziuni calcaroase, 5YR6/6. Ref. Popescu 2013, p. 175-176, Pl. 23, 58. Dat. sec. I p. Chr. Pl. III/19

20. Skyphos cu corpul tronconic, unghiular la joncțiunea dintre perete şi bază, cu toarte pliate la partea superioară. Cercetări arheologice 1949, Db. $4 \mathrm{~cm}$. Fragmentar. Corp tronconic, unghiular la joncțiunea peretelui cu baza inelară, profilată şi uşor supraînălțată; pasta este de culoare alb-gălbuie cu mică, oxizi de fier, 7,5YR6/4. Ref. Popescu 2013, p.180, nr. 577. Dat. sec. I p. Chr. Pl. III/20

\section{CUPĀ}

21. Cupă?. Cercetări arheologice 1949, Sect. K, demantelare profil ? carourile $6-8, D b=5,20 \mathrm{~cm}$. Fragmentar. Picior plat, suplu, cu marginea profilată având o canelură pe margine, pe partea interioară, plată, sunt trasate două cercuri concentrice; pasta este de culoare alb-gălbuie, fină, cu multe particule de mică aurie, 5YR6/6; firnis de culoare roșie, 5YR6/8. Ref.Atlante II, A6, Ceramica Candarli. Dat. sec. I p. Chr. Pl. IV/21, XI/17

\section{FARFURII}

22. Farfurie cu buză verticală şi muluri pe suprafața exterioară ${ }^{42}$ (Atlante II, tip I). Cercetări arheologice 1928 ?, B' C 12, Dg $=25 \mathrm{~cm}$. Fragmentar. Buză verticală, dreaptă la parte superioară, uşor arcuită la interior, delimitate cu muluri dispuse la partea superioară şi inferioară; pereții corpului sunt arcuiți; pasta este de culoare cărămizie, incluziuni calcaroase și mică, 7.5YR7/8; firnis de culoare portocalie, 5YR6/8; urme de ardere secundară. $C f$. Atlante II, 93, pl. XXII/6-8, 10; Zhuravlev 2002, 256, fig. 12/6. Ref. Vulpe, Teodor 2003, p. 323, no. 804, fig. 235/8; Popescu 2009, no. 1, p. 24, pl. 1; Dat. mijlocul sec. I p. Chr. Pl. IV/22, XI/18.

23. Farfurie (Atlante II, tip I). Cercetări arheologice 1949, H' IV A, $-1,00 \mathrm{~m}, \boldsymbol{D g}=16 \mathrm{~cm}$. Fragmentar. Buză verticală, dreaptă la parte superioară, ușor arcuită la interior, delimitate cu muluri dispuse la partea superioară și inferioară; pereții corpului sunt arcuiți; pasta este de culoare cărămizie, incluziuni calcaroase și mică, 7.5YR7/8; firnis de culoare portocalie, 5YR6/8. Cf. Atlante II, 93, pl. XXII/6-8, 10; Zhuravlev 2002, 256, fig. 12/6. Ref. Vulpe, Teodor 2003, p. 323, no. 804, fig. 235/8; Popescu

42 Popescu 2013, 221, pl. 11; tip P1/varianta 2; Atlante II, tip I; Zhuravlev 2010, 123-124, nr. 61, nr. 166, 167.
2009, no. 1, p. 24, pl. 1; Dat. mijlocul sec. I p. Chr. Pl. IV/23, XI/19

24. Farfurie cu corpul având pereții arcuiți şi buza rotunjită, teșită sau înclinată spre interior ${ }^{43}$ (Zhuravlev 2010, tipurile 11.1, 11.2 şi 12, Popescu 2013, tip P3/varianta 1). Cercetări arheologice $1949, D g=18 \mathrm{~cm}$. Fragmentar. Corp cu pereții arcuiți şi buza înclinată spre interior, teșită la vârf; pasta este de culoare cărămizie, fină, compactă, cu mică, incluziuni calcaroase, 5YR7/6; firnis de culoare portocalie, 5YR7/8. Ref. Vulpe, Teodor 2003, no. 796, p. 322, fig. 235/5. Dat. mijlocul sec. I p. Chr. Pl. IV/24, XI/20

28. Farfurie cu corpul având pereții arcuiți și buza rotunjită, teșită sau înclinată spre interior (Zhuravlev 2010, tipurile 11.1, 11.2 şi 12, Popescu 2013, tip P3/varianta 2). Cercetări arheologice 1949, $\boldsymbol{D g}=18 \mathrm{~cm}$. Fragmentar. Corp cu pereţii arcuiți și buza înclinată spre interior, teșită la vârf; pasta este de culoare cărămizie, fină, compactă cu incluziuni calcaroase, particule de mică în degresant, 2,5YR5/8. Firnis de culoare brun-roșcată 5YR7/8. Ref. Vulpe, Teodor 2003, nr. 796, p. 322, fig. 235/5. Dat. mijlocul sec. I p. Chr. Pl. IV/25, $\mathrm{XI} / 21$

29. Farfurie cu corpul având pereții arcuiți şi buza rotunjită, teșită sau înclinată spre interior ${ }^{44}$ (Zhuravlev 2010, tipurile 11.1, 11.2 și 12, Popescu 2013, tip P3/varianta 1). Cercetări arheolgice 1949, H' IV A, $-1,00 \mathrm{~m}, \boldsymbol{D g}=18 \mathrm{~cm}$. Fragmentar. Corp cu pereții arcuiți şi buza înclinată spre interior, teşită la vârf; pasta este de culoare cărămizie, fină, compactă, cu mică, incluziuni calcaroase, 5YR7/6; firnis de culoare portocalie, 5YR7/8. Cf. Zhuravlev 2002, 246, fig.4/9. Ref. Vulpe, Teodor 2003, no. 796, p. 322 , fig. 235/5. Dat. mijlocul sec. I p. Chr. Pl. IV/26, XI/22

30. Farfurie. Sigillata pergameniană. Cercetări arheologice $1949, D g=20 \mathrm{~cm}$. Fragmentar. Buză verticală, teşită la vârf, peretele vasului unghiular la joncţiunea buzei cu baza. Pastă compactă, dură cu incluziuni calcaroase şi oxizi de fier $10 \mathrm{YR} 6 / 1$; firnis metalic de culoare brun-roşcată 5YR3/4. Ref. Atlante II, tip L26A, Popescu 2013, p. 59, Dat. mijlocul sec. I a.Chr-finalul sec. I p. Chr. Pl. $\mathbf{X I} / 23$.

AMFORE

31. Amforă de tip pseudo Cos, sud-pontic, aparținànd probabil producției heracleene (Zeest ${ }^{45}$, Vnukov $^{46}$ ). Cercetări arheologice 1949, Sect. K, demantelare profil? carourile 2-5. Fragmentară. Toarte bifide, arcuite formând un unghi ascuțit. Pastă de culoare alb-rozie, fină, compactă, foarte

\footnotetext{
${ }^{43}$ Popescu 2013, 131-132, tip P3/varianta 1.

${ }^{44}$ Popescu 2013, 131-132; tip P3/varianta 1.

${ }^{45}$ Zeest 1960 , tipurile 61, 64, 65

${ }^{46}$ Vnukov 1999, 407-415
} 
dură, cu incluziuni albe, calcaroase, mică și cuarț, 7,5YR8/2. Ref. Opaiț 2011, 445-451. PI. V/27

32. Amforă de tip pseudo Cos, sud-pontic, aparținând probabil producției heracleene. Cercetări arheologice 1949, Secț. K, demantelare profil ? carourile 2-5. Fragmentară. Toarte bifide, arcuite formând un unghi ascuțit; pastă de culoare albrozie, fină, compactă, foarte dură, cu incluziuni albe, calcaroase, mică, cuarț 7,5YR8/2. Ref. Opaiț 2011, 445-451. PI. V/28

$V A R I A$

CUPĂ

33. Cupă cu corpul globular nedeterminabilă ca tip. Cercetări arheologice 1949; $\boldsymbol{D g}=8 \mathrm{~cm}$. Fragmentar. Corp globular cu pereți fini, buză rotunjită; pasta este de culoare cărămiziu-gălbuie, fină, compactă cu particule de mică și oxizi de fier, 7,5YR7/6. Pl. V/29

\section{IMITAȚII GETICE}

\section{SKYPHOI}

34. Skyphos cu corpul tronconic, unghiular la joncţiunea dintre perete şi bază, cu toarte pliate la partea superioară ${ }^{47}$. Cercetări arheologice 1950 , Sect. K, demantelare profil? carourile 6-8, Dg. 14,5 $\mathrm{cm}$. Fragmentar. Corp tronconic, unghiular la joncțiunea dintre perete și bază, cu buza rulată şi rotunjită a exterior; toarta verticală, pliată, cu o uşoară şănțuire la partea superioară; pasta este de culoare galben-cărămizie, cu nisip, incluziuni de culoare neagră şi oxizi de fier, 7,5YR6/6; firnis de culoare roșie păstrat parțial. Pl. VI/31, X/13

35. Skyphos cu corpul tronconic, unghiular la joncțiunea dintre perete şi bază. Cercetări arheologice 1949, $D g=8 \mathrm{~cm}, D m=8,80 \mathrm{~cm}, D b=$ $5 \mathrm{~cm}$. Fragmentar. Marginea este rotunjită spre exterior, arcuită, rotunjită; corpul este tronconic, toartele sunt verticale, uşor pliate la partea superioară, baza vasului este inelară; Dec. Benzi pictate cu roșu dispuse orizontal pe buză şi în zona diametrului maxim încadrând benzi oblice (motiv geometric). Pasta este fină de culoare gălbuie, cu incluziuni calcaroase, oxizi de fier, cărbune? 5YR6/6. Pl. VI/32, X/14

36. Skyphos cu corpul tronconic, unghiular la joncțiunea dintre perete şi bază. Cercetări arheologice 1928?, secț. B' C 12, Dg $=11 \mathrm{~cm}, \mathbf{D m}$ $=12 \mathrm{~cm}$. Fragmentar. Corpul este globular, toartele lipsesc, probabil inelare cu plăcuță, buza dreaptă, subțiată la vârf. Pasta este fină, de culoare gălbuie, cu incluziuni calcaroase, particule de mică şi nisip în degresant, 10YR7/6. Dec. Benzi pictate de culoare roșie dispuse pe buză și la partea inferioară

47 Popescu 2013, 87; analogii cu un fragment passim descoperit la Brad. încadrând linii oblice (motiv geometric). Pl. VI/33, $\mathrm{X} / \mathbf{1 5}$

37. Skyphos imitație cu două toarte inelare ${ }^{48}$. Cercetări arheologice $1949, D m=10 \mathrm{~cm}$. Fragmentar. Corp de formă tronconică, unghiular la joncțiunea peretelui cu baza; toarte inelare cu şănțuire mediană în secțiune; pasta este culoare albgălbuie, cu mică şi oxizi de fier 7,5YR6/6; fimisul nu se mai păstrează. PI. V/30

38. Skyphos cu corpul tronconic, rotunjit la joncțiunea dintre perete şi bază, cu toarte pliate la partea superioară. Cercetări arheologice 1950, Secț. $\mathrm{K}$, demantelare profil ? carourile $6-7, \boldsymbol{D g}=11,2$ $\mathrm{cm}$. Fragmentar. Corp globular cu buza rotunjită, toartele sunt verticale, pliate la partea superioară. Dec. Pereții vasului sunt decorați cu linii verticale lustruite, dispuse paralel pe suprafața mată a angobei; pasta este de culoare cenușie, fină, cu nisip, mică, oxizi de fier, 5PB5/6 B. PI. VII/35, XII/34

39. Skyphos. Cercetări arheologice 1949 Sect. K, demantelare profil ? carourile $6-8, D g=9 \mathrm{~cm}$; Fragmentar. Corp tronconic cu toarta inelară prinsă sub buza evazată, rotunjită la exterior; pasta este fină, compactă, de culoare cenușie, conținând nisip, mică, oxizi de fier, 5/10Y. PI. VII/36, XII/36.

40. Skyphos. Cercetări arheologice 1949 sect. K, demantelare profil? carourile 6-8, $D m=7,20 \mathrm{~cm}$. Fragmentar. Corpul de formă tronconică, rotunjit la joncțiune peretelui cu baza; pasta este de culoare cenușiu-negricioasă, fină, compactă, cu nisip și incluziuni calcaroase, 5/5 PB. Dec. benzi verticale, dispuse paralel pe suprafața mată a angobei. PI. VII/37

41. Skyphos. Cercetări arheologice 1949, $D g=8$ $\mathrm{cm}$., $\boldsymbol{D} \boldsymbol{m}=9 \mathrm{~cm}$. Fragmentar. Corpul de formă tronconică, cu o mulură la joncțiunea peretelui cu baza, buza este rotunjită, înclinată spre exterior; pasta este de culoare cenuşiu-negricioasă, fină, compactă, cu nisip şi incluziuni calcaroase, 5/5 PB. Dec. benzi verticale, dispuse paralel pe suprafaţa mată a angobei. PI. VII/38

42. Skyphos. Cercetări arheologice 1949, Secț. K, demantelare profil ? carourile $6-8 ; D \boldsymbol{m}=9,50 \mathrm{~cm}$. Fragmentar. Corp de formă bitronconică; pasta este de culoare cenuşie, compactă, cu particule de mică, oxizi de fier, incluziuni cenuşii, 5GY. Dec. lustruit şi format din benzi dispuse oblic pe suprafața matā a angobei. Pl. VII/39

43. Skyphos. Cercetări arheologice $1949, L=3,50$ $\mathrm{cm}, l=3,40 \mathrm{~cm}$. Fragmentar. Toarta cu plăcuță, specifică cănilor de tip „Boscoreale ${ }^{, 49}$; pasta este de culoare gălbui-cărămizie, fină, compactă, cu particule de mică şi oxizi de fier, 5YR5/8. PI. VII/34

${ }^{48}$ Popescu 2013, 88, analogii cu o descoperire de la Răcătău.

49 Ar putea fi un produs autohton, diferenţierea originalului de copie este greu de făcut în lipsa unor analize specifice. 


\section{LAGYNOS}

44. Lagynos. Cercetări arheologice 1949 ?. Fragmentar. Se păstrează un fragment din corpul angular al vasului; pasta este fină, dură, de culoare gălbuie, cu incluziuni calcaroase, particule de mică şi nisip în degresant, 10YR7/6. Dec. Benzi pictate de culoare roşie, benzi oblice ce formează triunghiuri cu baza sprijinită pe una din benzile dispuse orizontal (motiv geometric). Pl. X/16.

KANTHAROI

45. Kantharos Cercetări arheologice 1949, Secț. H', 1949. Dm $=7 \mathrm{~cm}, \boldsymbol{D b}=5 \mathrm{~cm}$. Fragmentar. Corp de formă tronconică cu pereți drepți şi toarte rotunjite (ovoidale în secțiune), sprijinit pe un picior suplu de formă inelară; pasta este de culoare cenuşie, fină cu oxizi de fier, nisip, particule de mică, incluziuni calcaroase în degresant, 5PB5. PI. VIII/40, XII/24 46. Kantharos. Cercetări arheologice 1928? Secț. B' C $12, \boldsymbol{D g}=11 \mathrm{~cm} ; \boldsymbol{D b}=6 \mathrm{~cm}$. Fragmentar. Corp tronconic cu o mulură la joncțiunea peretelui cu baza, toarta prinsă sub buză, bază inelară; pasta este fină de culoare cenuşie, având incluziuni calcaroase, cărbune şi oxizi de fier, 5PB5/6. PI. VIII/41, XII/25

47. Kantharos. Cercetări arheologice 1949; PK dem $2-5, D g .8 \mathrm{~cm}, D \boldsymbol{m}=8,80 \mathrm{~cm}$. Fragmentar. Corp de formă tronconică; pastă fină, compactă de culoare cenușie, având ca degresant nisip, 5PB5/6. Dec. caneluri, linii oblice și meandrice. PI. VIII/42, XII/26

48. Kantharos. Cercetări arheologice 1949; Secț. K, demantelare profil ? carourile $2-5, D g=10 \mathrm{~cm}$. Fragmentar. Buza este canelată cu patru caneluri; pasta este de culoare cenușie, fină, cu incluziuni calcaroase și cărbune, 5/6 PB. Dec. linii lustruite, dispuse oblic, formând triunghiuri sau omamente în formă de „U” întors, cele două motive fiind despărțite printr-o canelură. PI. VIII/43, XII/27

\section{BOL EMISFERIC CU DECOR ÎN RELIEF}

49. Bol. Cercetări arheologice $1949, D m .16 \mathrm{~cm}$, Db. $7 \mathrm{~cm}$. Fragmentar. Corp emisferic; pastă de culoare cenuşie, compactă, cu nisip şi incluziuni calcaroase, 6/5 PB. Dec. medalion cu incizii şi încrustaţii neuniforme. Pl. VIII/44, XII/28

Mulțumesc cu această ocazie cercetătorului şi colegului George Trohani pentru interesul şi ajutorul oferit, dar şi colegei de la Muzeul Național de Istorie a Transilvaniei, Mariana-Cristina Popescu pentru îndemn şi pentru discuțiile purtate. Last but not least, îi mulțumesc artistului grafic și colegei Simona Movilă pentru ajutorul dat în desenarea materialului care ilustrează acest articol.

\section{BIBLIOGRAFIE}

Atlante II

Bauer 2008

Cleșiu, Trohani 2013

Dumitrescu, Vulpe 1988

Florea 1998

Florea 2011

Fontes I

Hodder, Hutson 2003

Lungu, Trohani 2000

Opaiț 2013

Petolescu 2010
Atlante delle forme ceramiche II: Ceramica fine romana del bacino mediterraneo (tardo ellenismo e primo impero) (EAA Suppl. 2), Rome, 1985 A. A. Bauer, Import and Imitation in Archaeology, în Import, Imitation or Communication? Pottery style, Technology and Coastal Contact in the Early Bronze Age Black Sea, Langenweißbach, 2008 p. 89-104

S. Cleșiu, G. Trohani, Restitutio. La céramique a décor peint de Sarmizegetusa Regia des dépots des Muséees de Bucarest, Eph. Nap., XXIII, 2013, p. 205-243

Dacia inainte de Dromihete, București 1988, p. 92

G. Florea, Ceramica pictată. Artă meșteșug și societate în Dacia preromană (sec. I a. Chr. - I p. Chr.), Cluj-Napoca, 1988

G. Florea, Dava et Oppidum. Débuts de la genèse urbaine en Europe aux deuxième âge du Fer, Cluj-Napoca, 2011, 83

Fontes Historiae Daco-Romanae I, București 1964, p. 467-471

I. Hodder, S. Hutson, Reading the Past. Current approaches to interpretation in archaeology, Cambridge University Press, 2003, p. 144

V. Lungu, G. Trohani, Vases hellénistiques à décor peint de la plaine roumaine, Istro-Pontica. Muzeul tulcean la a 50-a aniversare, 1950-2000: omagiu Simion Gavrilă la 45 de ani de activitate 1955-2000, p. 137-162

A. Opaiț, Producția și consumul de vin în ținuturile dintre Carpați şi Marea Neagră (secolele II a. Chr - III p. Chr.): Unele considerații, SCIVA, 64, 1-2, București, 2013, p. 21-65

C. C. Petolescu, Dacia. Un mileniu de istorie, București, 2010 
Petre 2004

Popescu 2009

Popescu 2010

Popescu 2012

Popescu 2013

Syme 1971

Vnukov 1999

Vulpe 1931

Vulpe 1951

Vulpe, Teodor 2003

Zhuravlev 2002

Zhuravlev 2010

Zeest 1960
Zoe Petre, Practica nemuririi. O lectură critică a izvoarelor grecești referitoare la geți, București, 2004

Mariana-Cristina Popescu, Pontic sigillata discovered in the dacian settlement of Poiana, Nicorești commune, Galaţi county, în O. Tentea, F. Matei-Popescu (eds.), Near and Beyond the Roman Frontier. Proceedings of a Colloquim held in Târgovişte, 16-17 October 2008, 2009, p. 17-46

Mariana-Cristina Popescu, Pergamian Pottery discovered in Geto-Dacian sites $\left(2^{\text {nd }}-1^{\text {st }}\right.$ centuries $\left.B C\right)$, Caiete ARA, 1, 2010, p. 51-66

Mariana-Cristina Popescu, Data on the Lead-glazed Pottery Discovered on the Dacian Sites Brad (Bacău Co.) and Poiana (Galati Co.), Caiete ARA, 3, 2013, p. $5-10$

Mariana-Cristina Popescu, Hellenistic and Roman Pottery in pre-Roman Dacia: ( $2^{\text {nd }}$ century B.C. - $I^{\text {st }}$ century A.D.), Cluj-Napoca, 2013

R. Syme, Emperors and Biography: Studies in the Historia Augusta, Oxford University Press, 1971

S.Y Vnukov, Pan-Roman Amphora Types Produced in the Black Sea Region, în Y. Garlan (ed.), Production et Commerce des amphores ancienne en mer Noir, Aix-en-Provence, 1999, p. 407-415

R. Vulpe, Piroboridava. Consideratii arheologice și istorice asupra Cetătuiei de la Poiana in Moldova de Jos, București, 1931

R. Vulpe, Santienul Poiana, SCIV 2, 1951, p. 177-216

R. Vulpe, Silvia Teodor, Piroboridava. Așezarea dacică de la Poiana, București, 2003

D. V. Zhuravlev, Terra Sigillata and Red Slip Pottery in the North Pontic Region (A Short Bibliographical Survey), în Ancient Civilization from Scythia to Siberia, vol. 8, nr. 3-4, 2002, p. 237-309

D. V. Zhuravlev, Crasnolacovaia cheramica Iugo-Zapadnavo Crîma I-III $V V ., N . \not .$, Simferopol, 2010

I. B. Zeest, Keramiceskaja tara Bospora, Materialy $i$ issledovanja po arheologii, Moskva, 83, 1960 


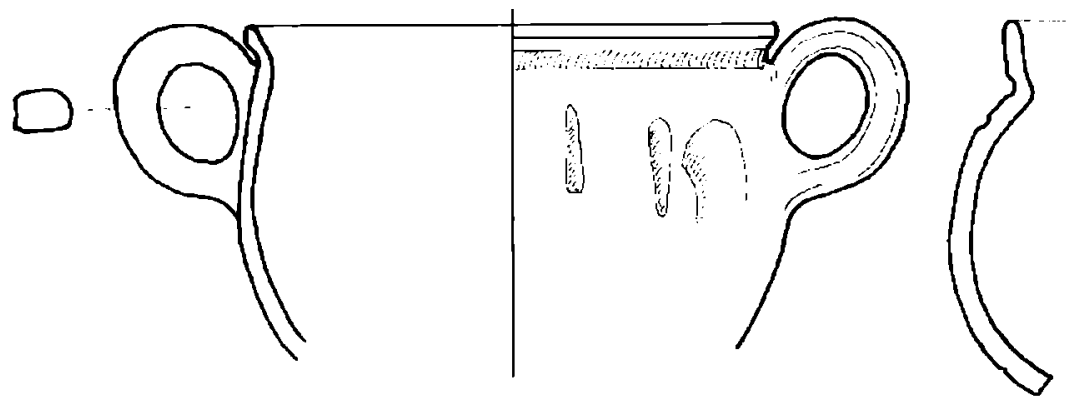

1.

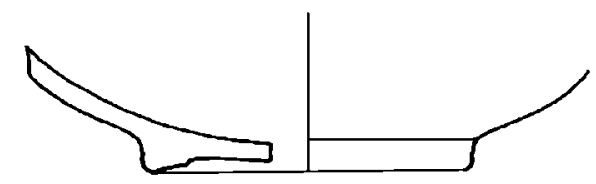

3.

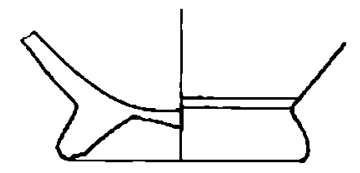

5.

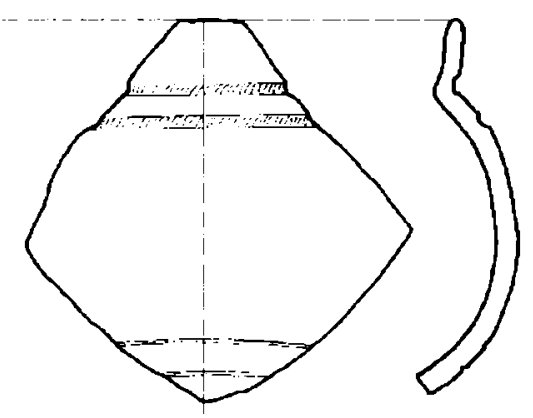

2.

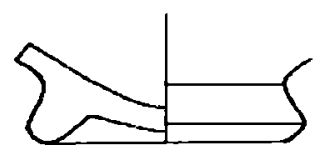

4.

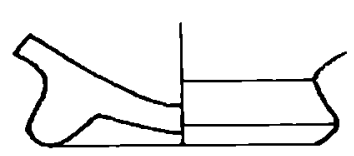

6.

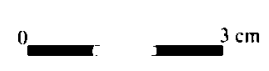



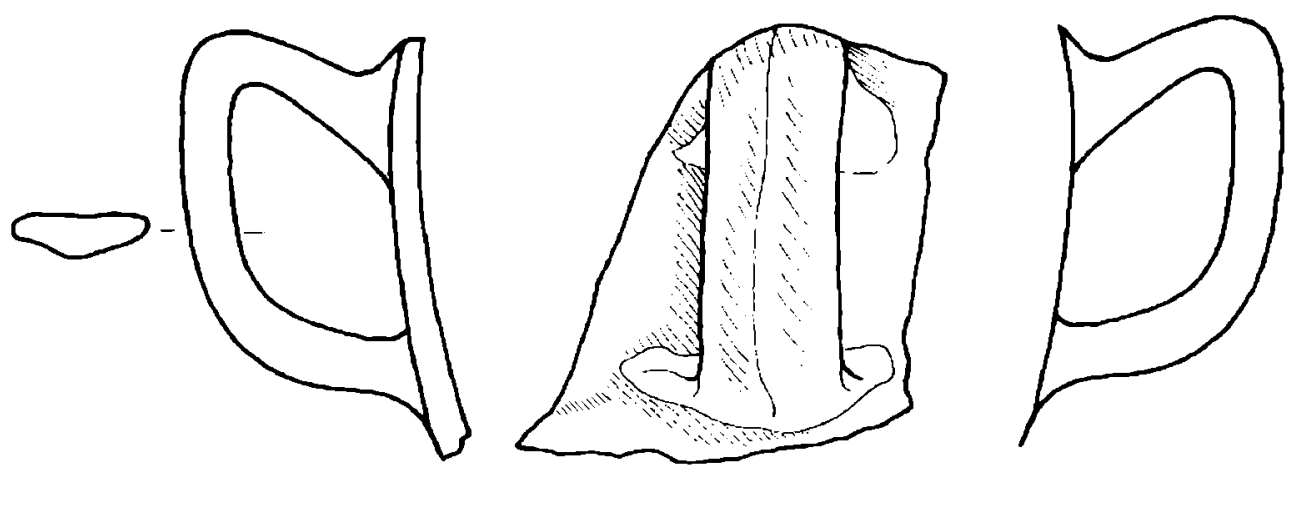

7.
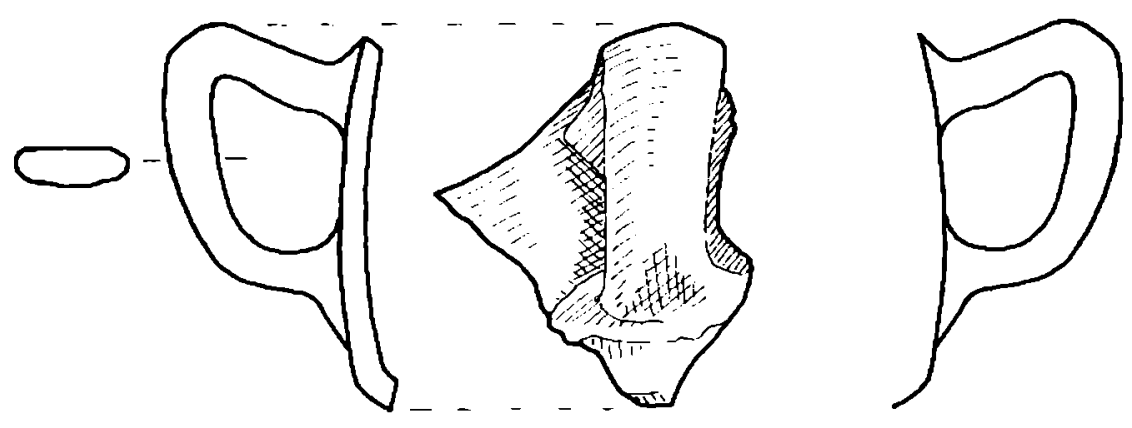

8.

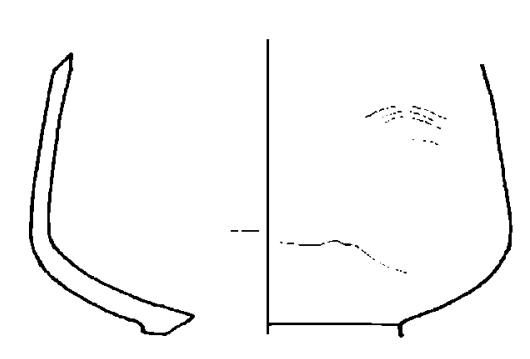

9.

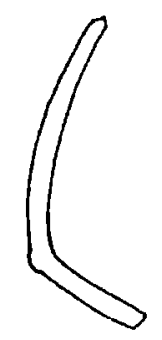

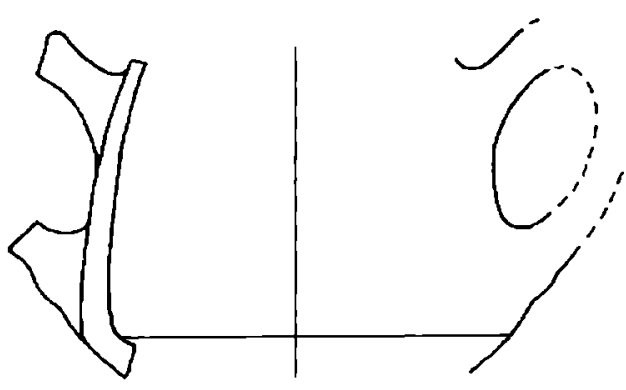

10.

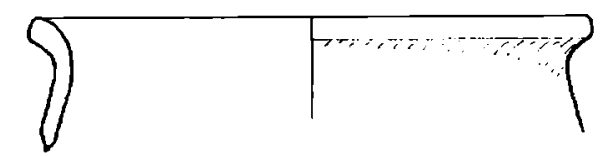

12.

11.

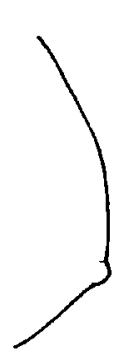

1.

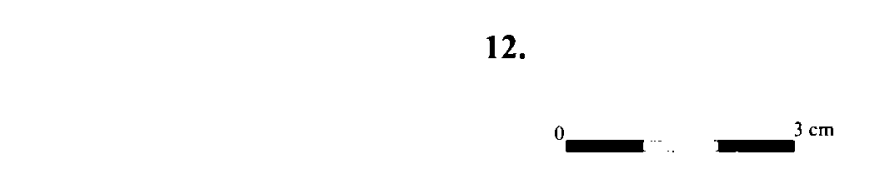

Skyphoi

PI. II 


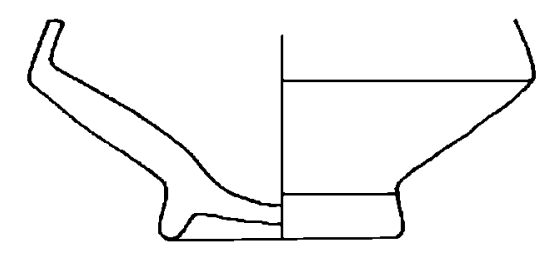

13.

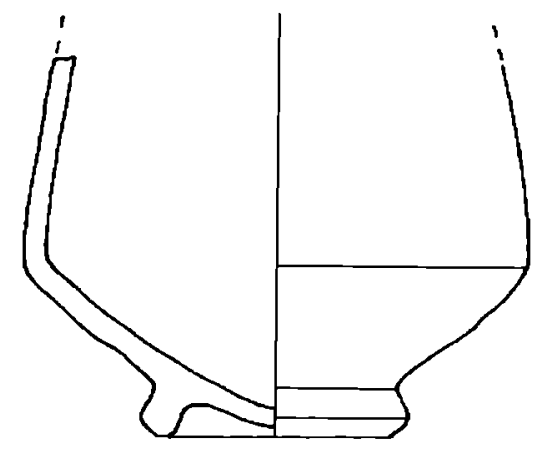

15.

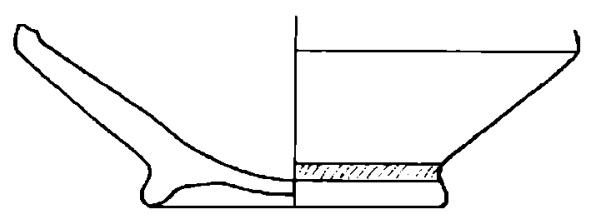

17.

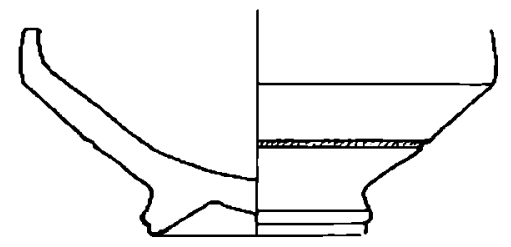

19.

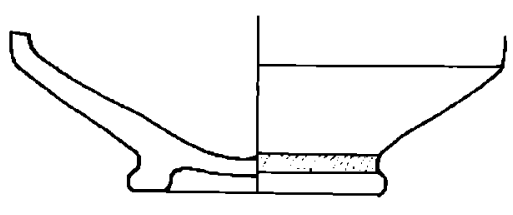

14.

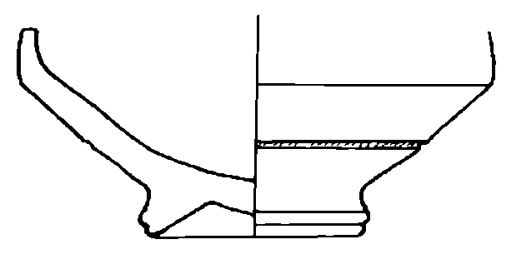

16.

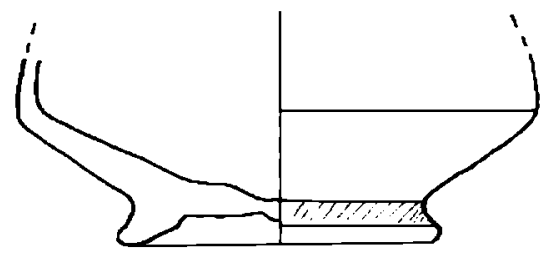

18.

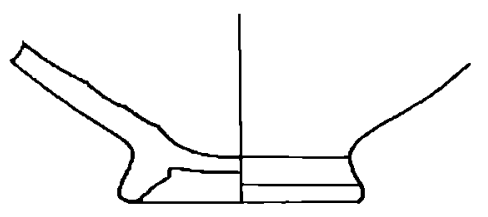

20.

${ }^{0}-\mathbf{m}^{3 \mathrm{~cm}}$ 


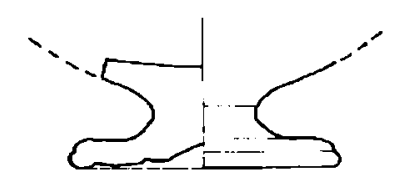

21.

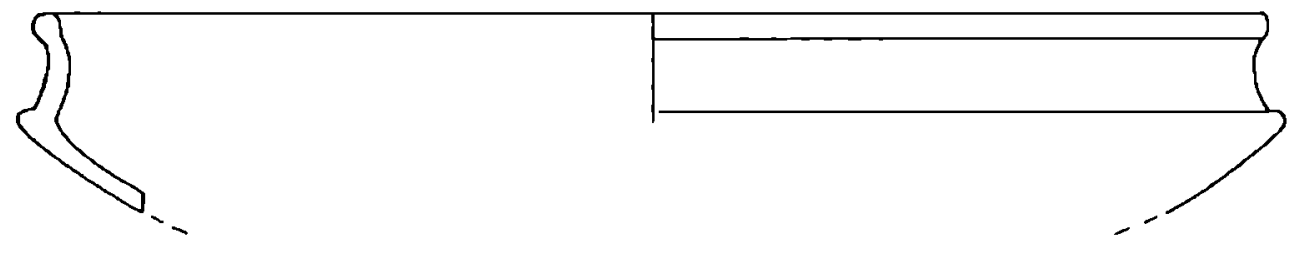

22.

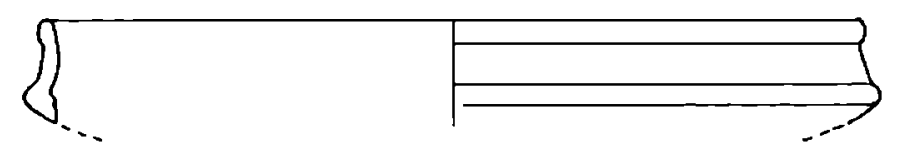

23.

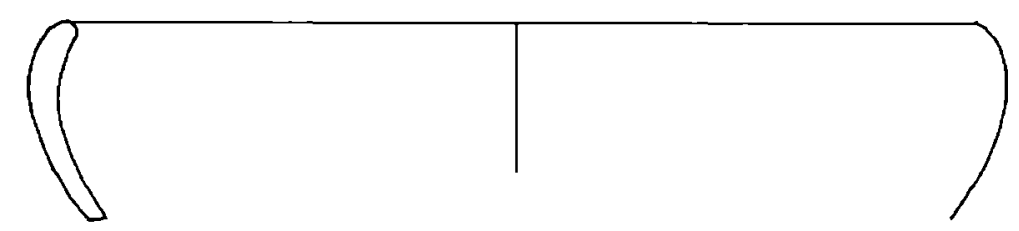

24.

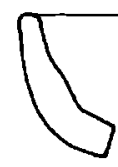

25.

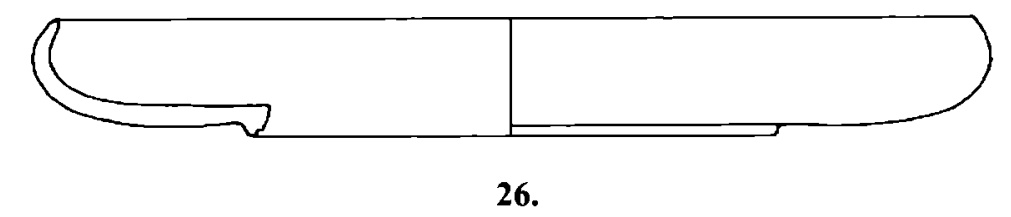

$0 \quad m^{3 \mathrm{~cm}}$ 


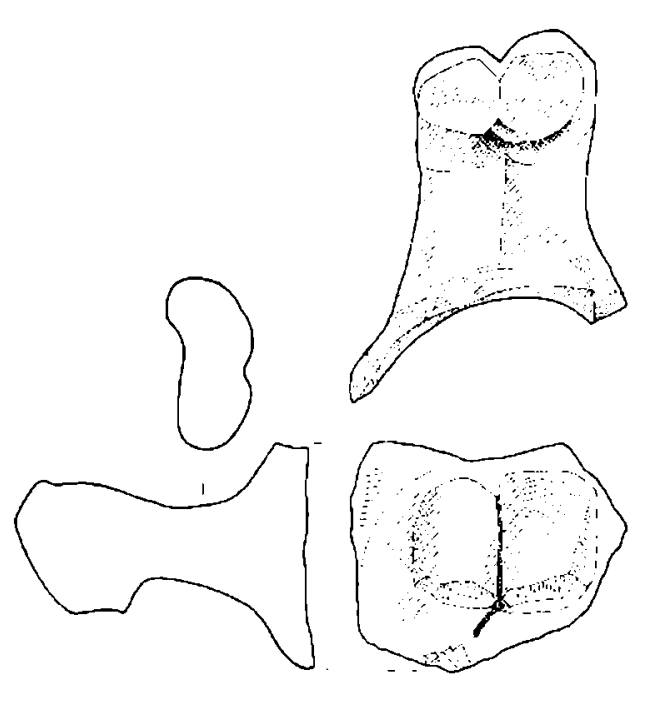

27.

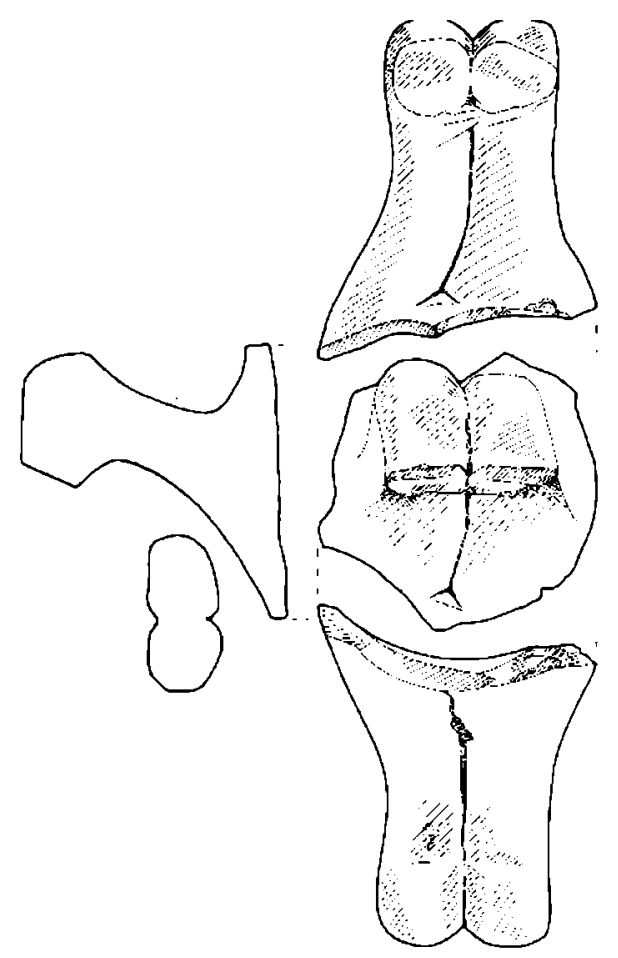

28.

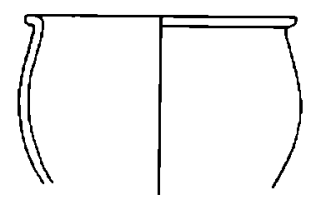

29.

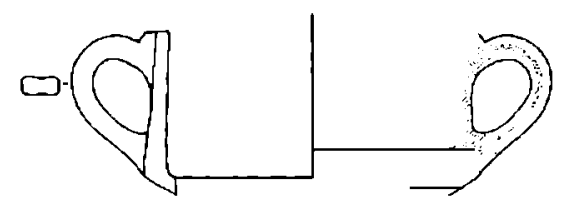

30.

${ }^{0}-=^{3 \mathrm{~cm}}$

Amfore, Imitaţii getice, Varia

PI. V 


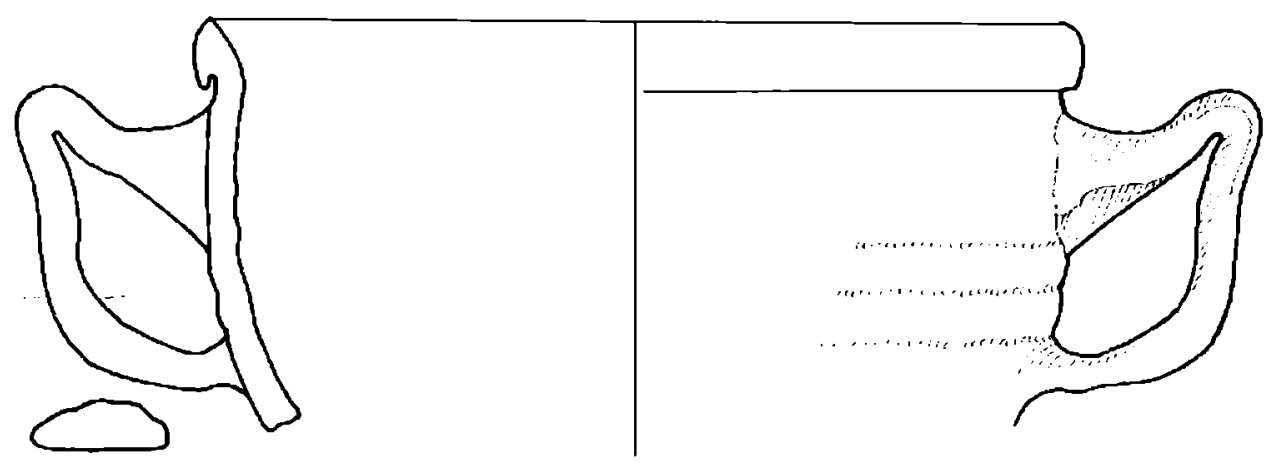

31.

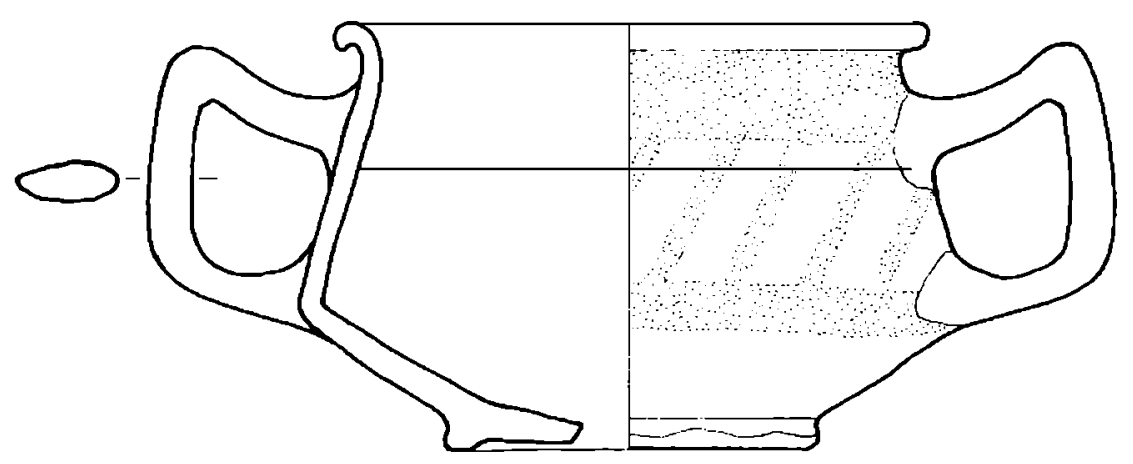

32.

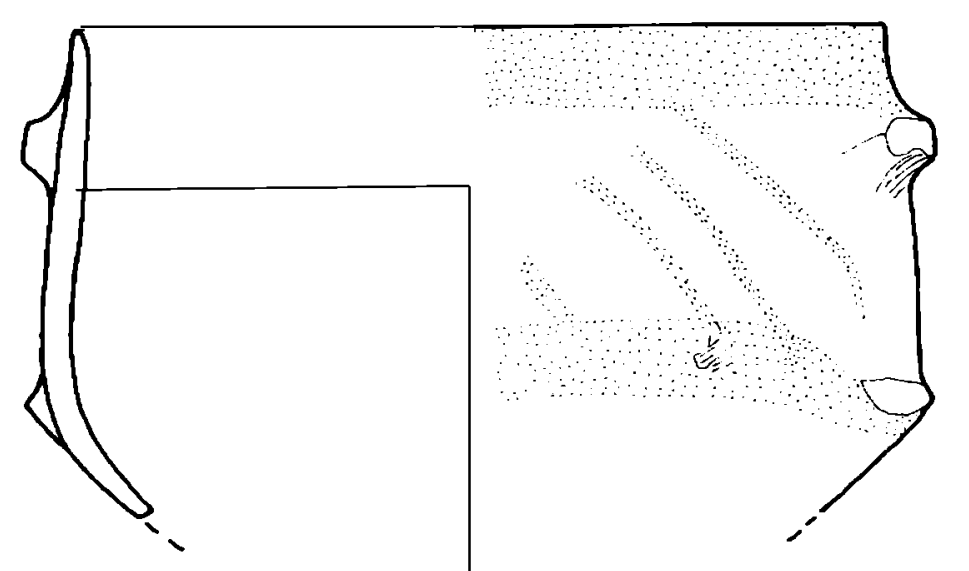

33.

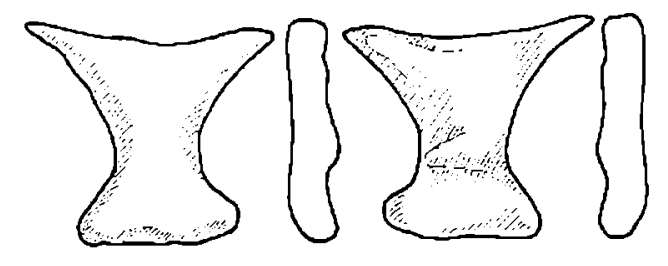

34.

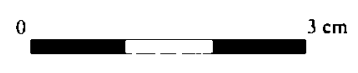

Imitații getice (skyphoi)

PI. VI 


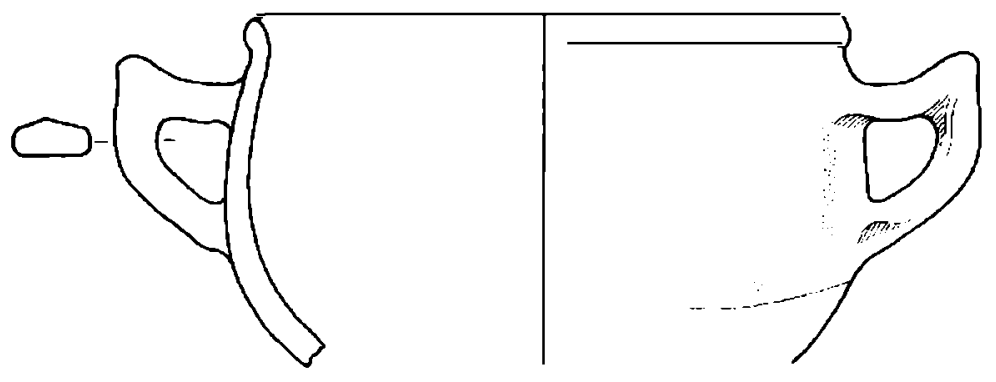

35.

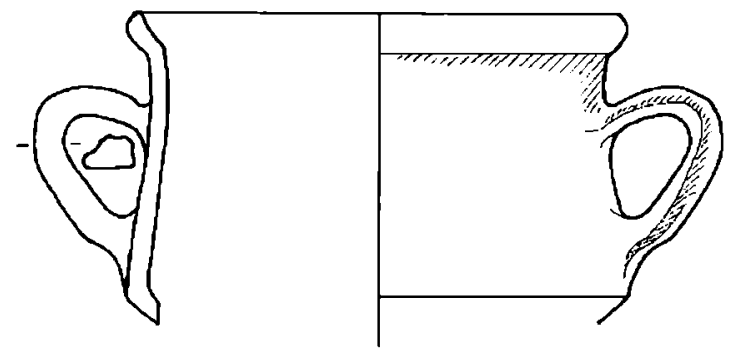

36.
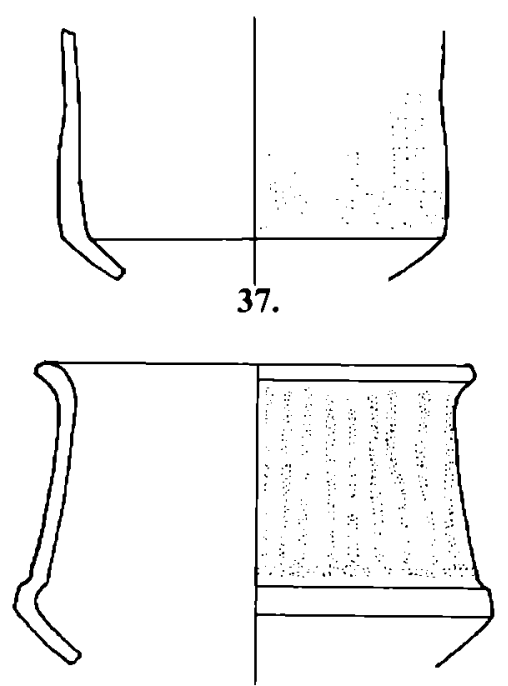

38.

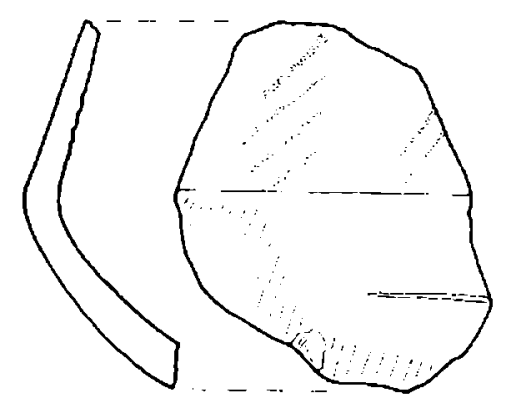

39.

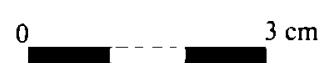

Imitații getice (skyphoi) 


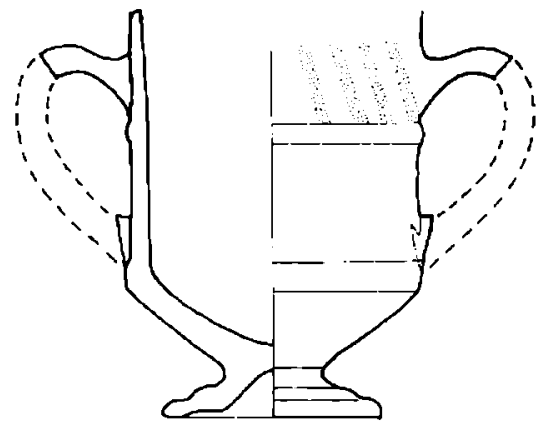

40.

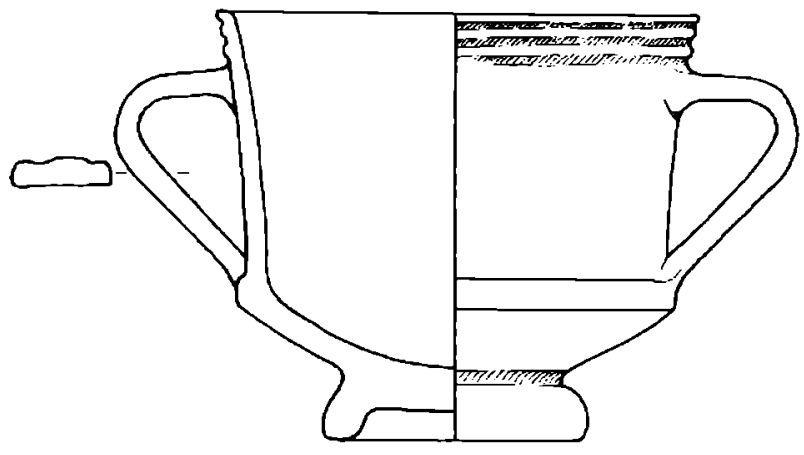

41.

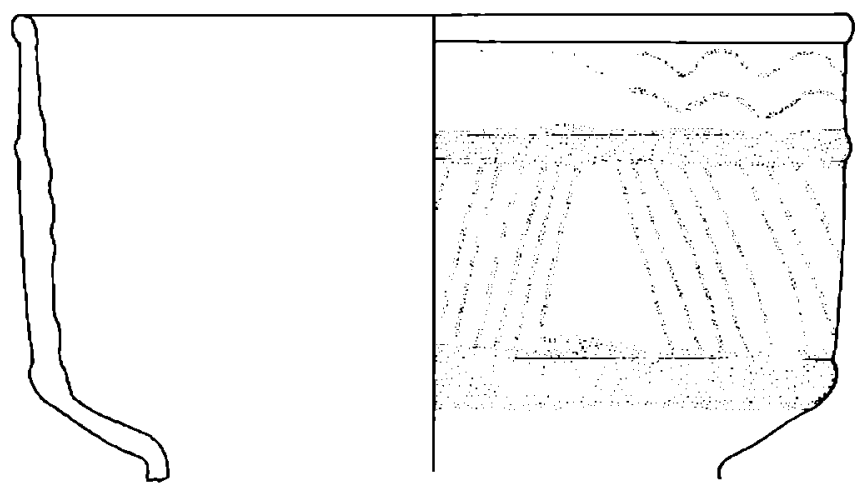

42.

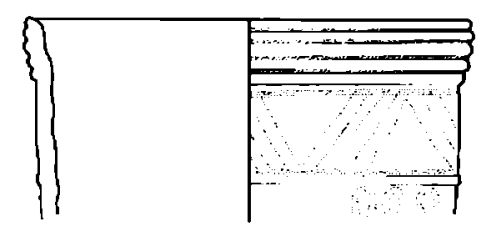

0

43.
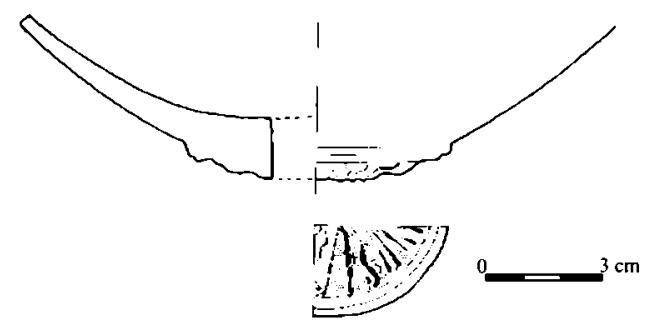

44.

Imitații getice (kantharoi, boluri) 

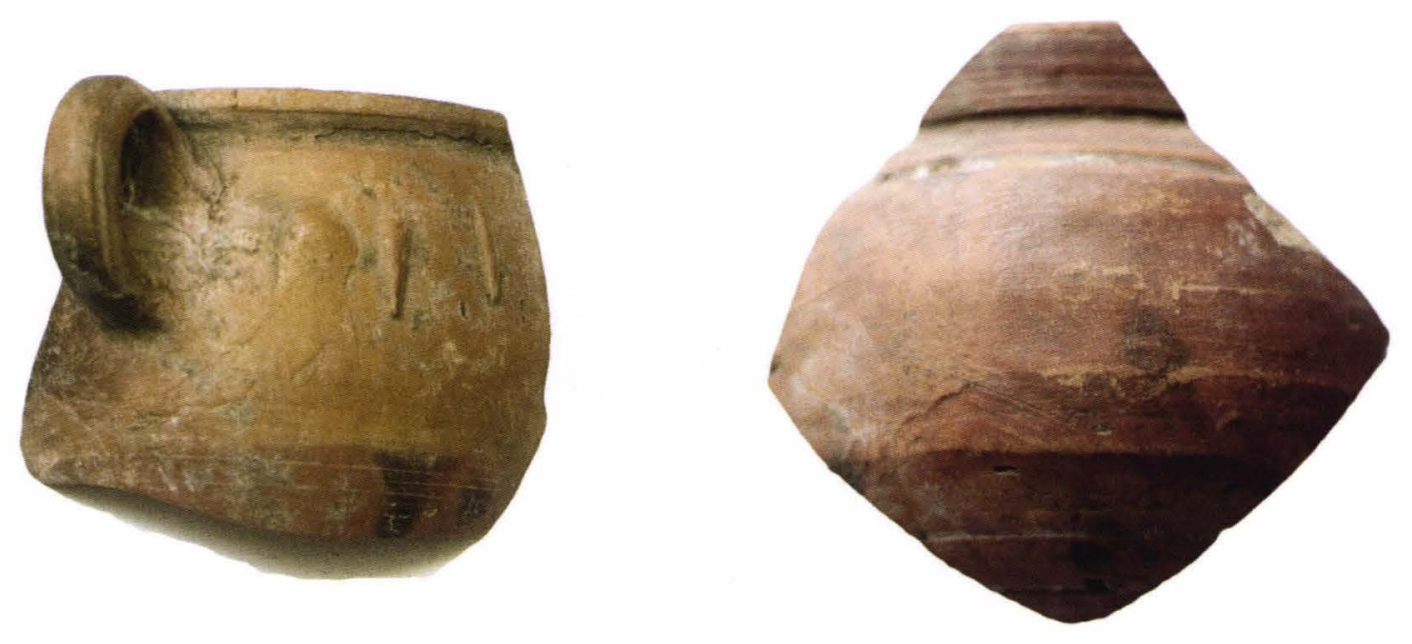

1.

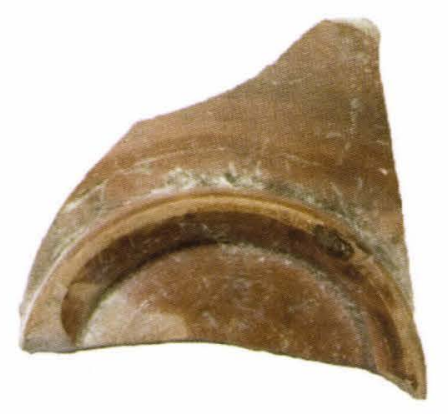

3.

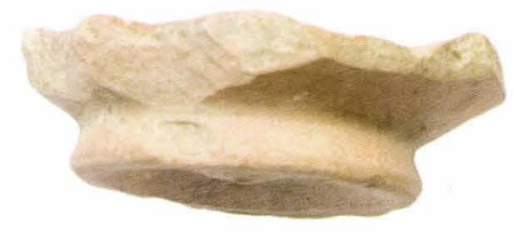

5.
2.

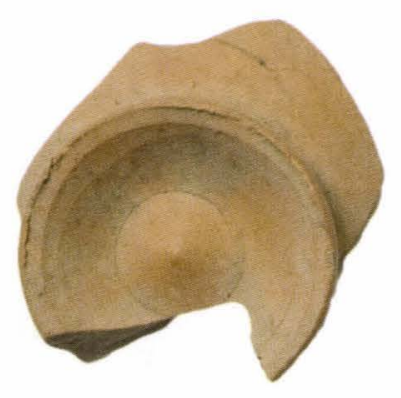

4.

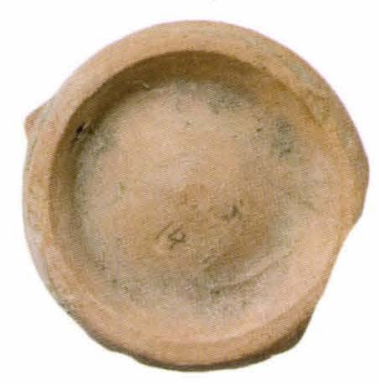

6.

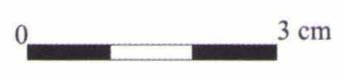




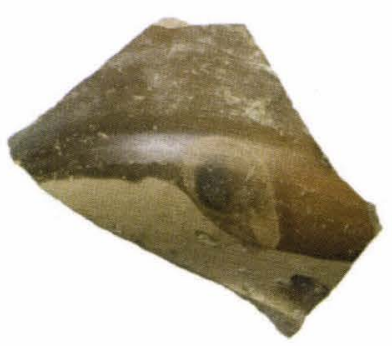

7.

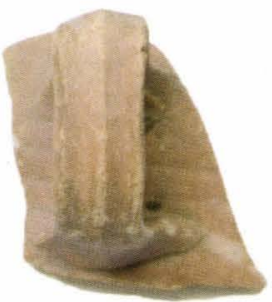

10.

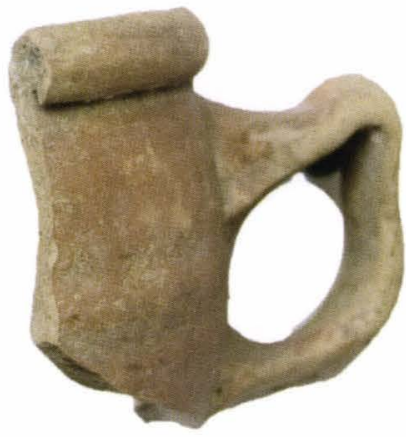

13.
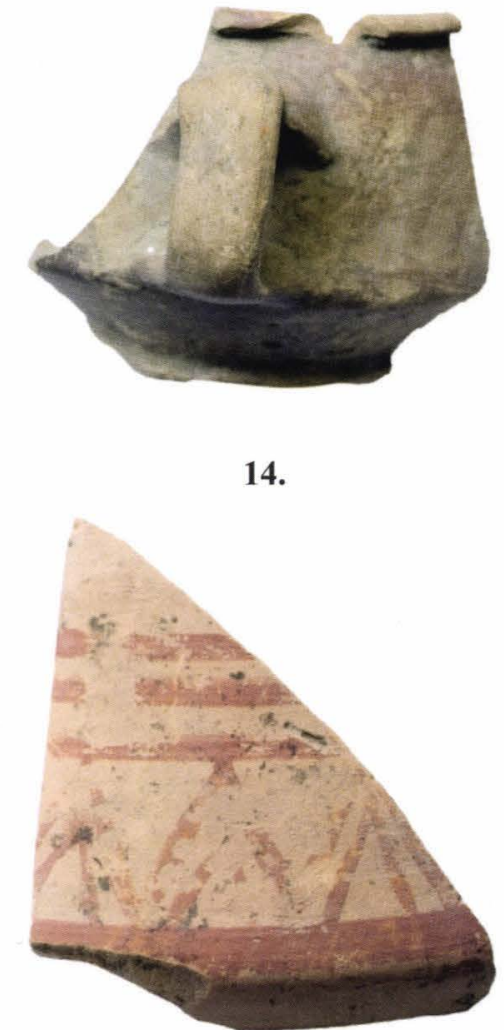

16.
14.

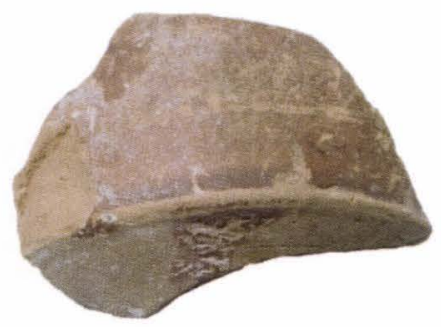

9.

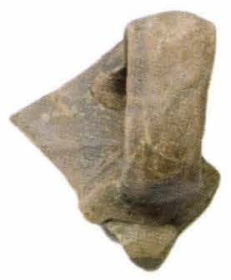

11.

12.

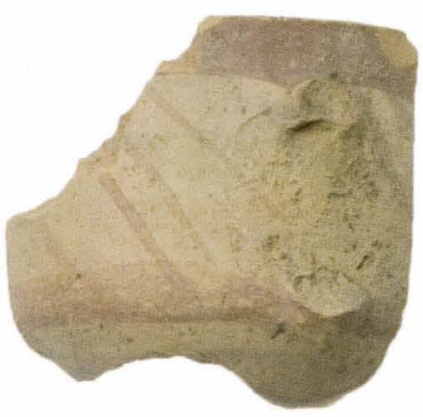

15.

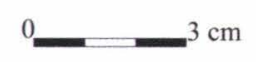

Skyphoi, Imitații getice (skyphoi, lagynoi)

PI. X 


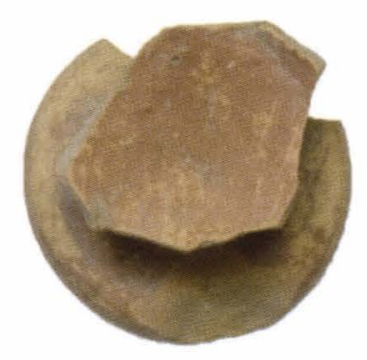

17.

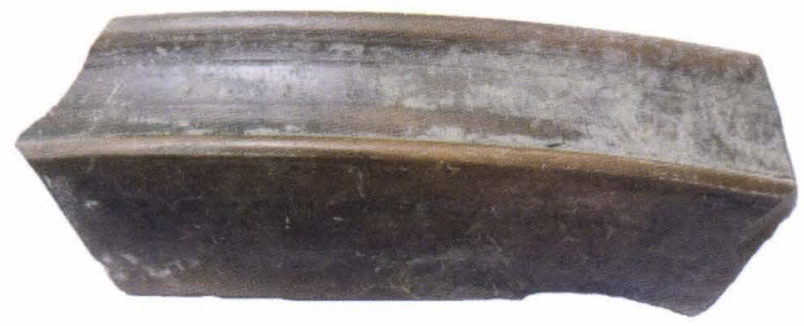

18.
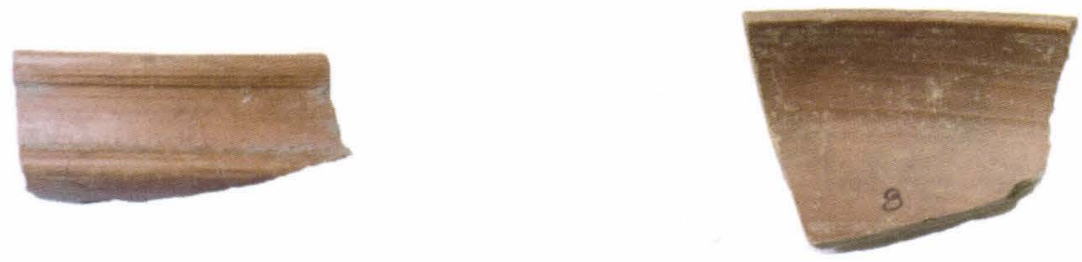

19.

20.
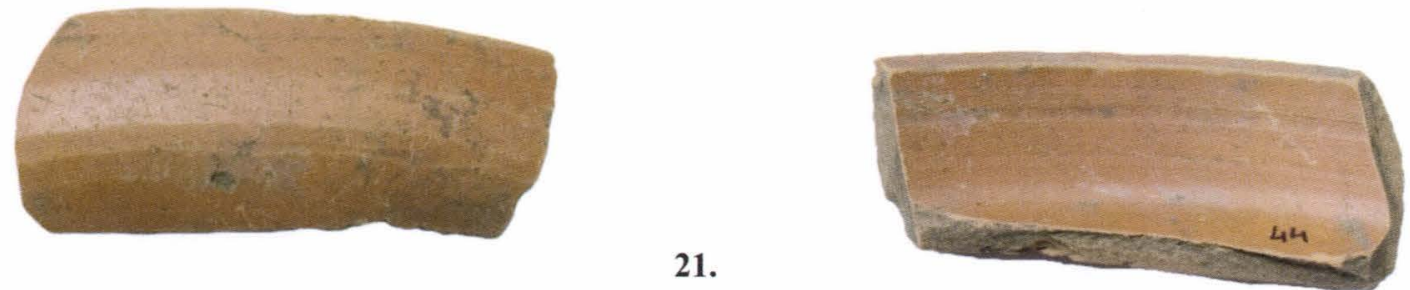

21.

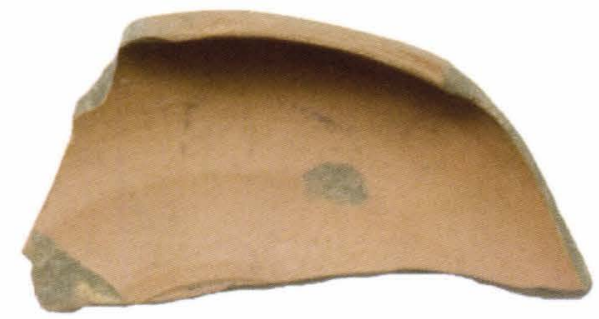

22.
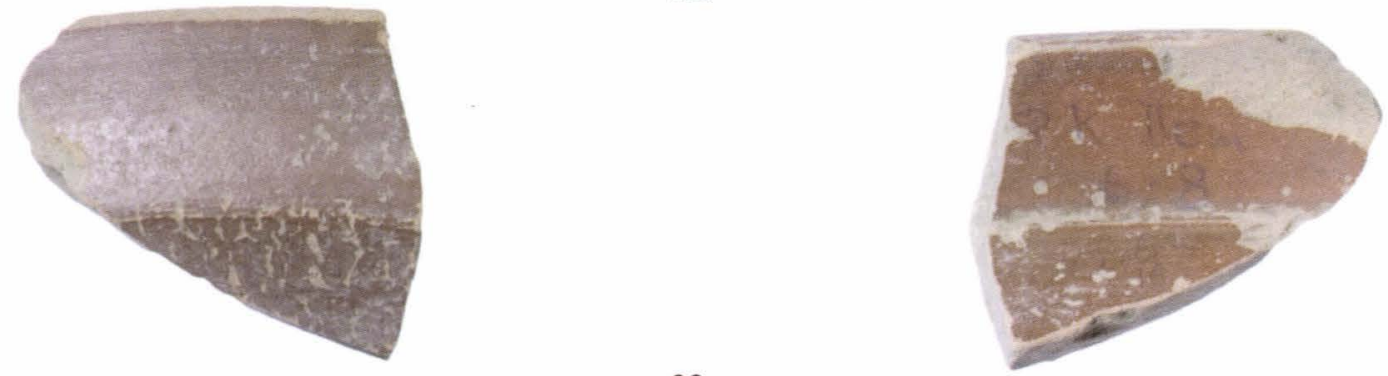

23.

Farfurii

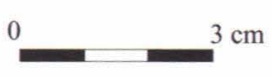

PI. XI 


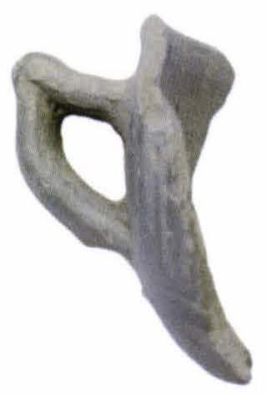

24.

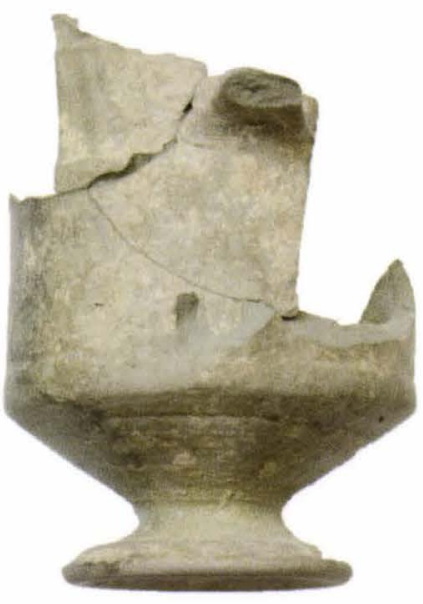

26.

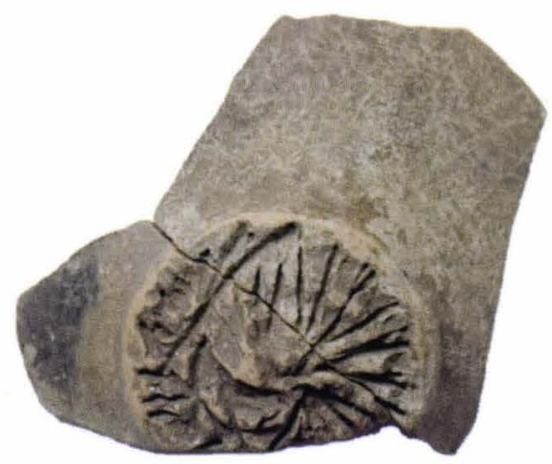

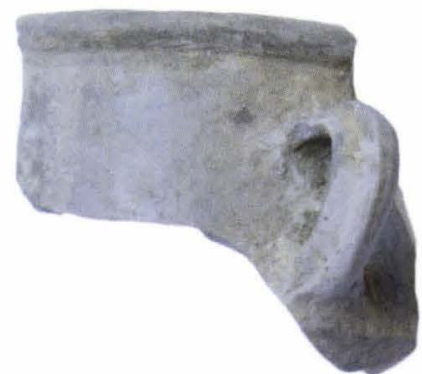

25.

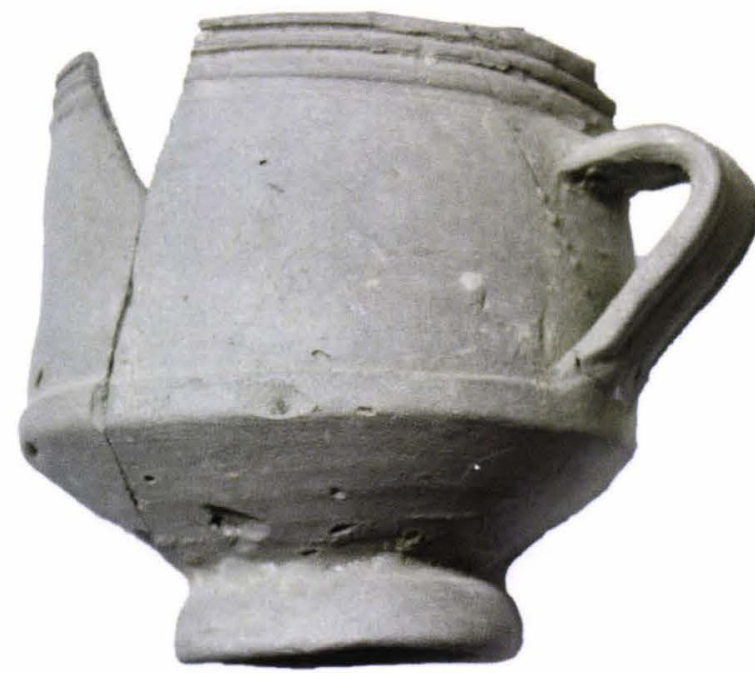

27.

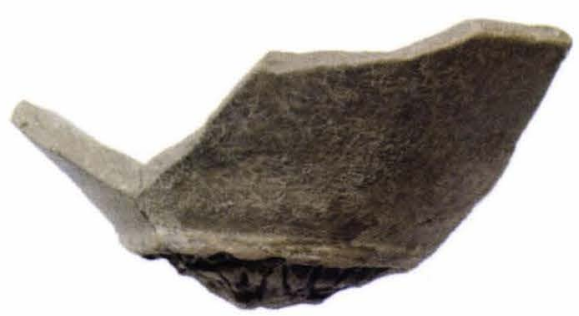

28.

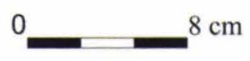

Imitații getice (skyphoi, kantharoi)

\section{PI. XII}

